\title{
Evaluation of a Dry Process for Conversion of U-AVLIS Product to UF 6 Milestone U361
}

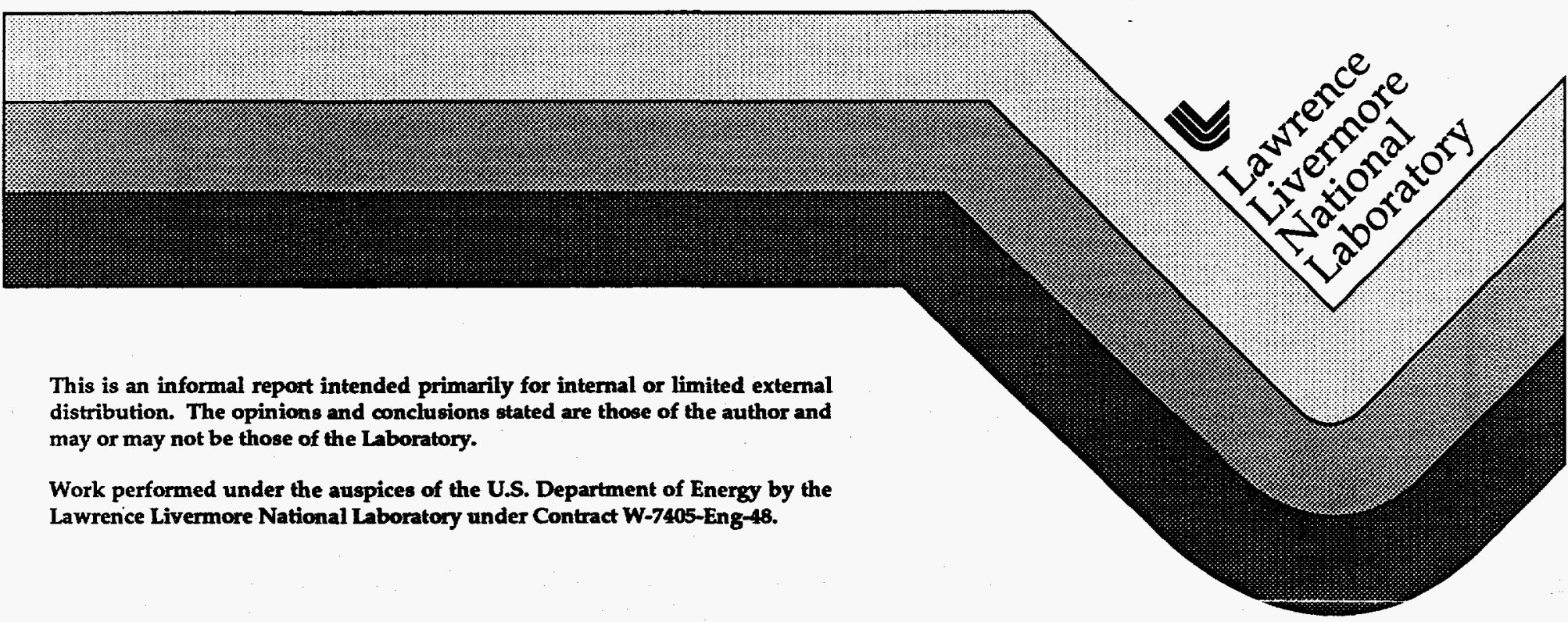




\section{DISCLAIMER}

This document was prepared as an account of work sponsored by an agency of the United States Government. Neither the United States Government nor the University of California nor any of their employees, makes any warranty, express or implied, or assumes any legal liability or responsibility for the accuracy, completeness, or usefulness of any information, apparatus, product, or process disclosed, or represents that its use would not infringe privately owned rights. Reference herein to any specific commercial product, process, or service by trade name, trademark, manufacturer, or otherwise, does not necessarily constitute or imply its endorsement, recommendation, or favoring by the United States Government or the University of California. The views and opinions of authors expressed herein do not necessarily state or reflect those of the United States Government or the University of.California, and shall not be used for advertising or product endorsement purposes.

This report has been reproduced directly from the best available copy.

Available to DOE and DOE contractors from the Office of Scientific and Technical Information

P.O. Box 62, Oak Ridge, TN 37831

Prices available from (615) 576-8401, FTS 626-8401

Available to the public from the

National Technical Information Service

U.S. Department of Commerce

5285 Port Royal Rd.

Springfield, VA 22161 


\section{DISCLAIMER}

Portions of this document may be illegible in electronic image products. Images are produced from the best available original document. 


\section{Evaluation of a Dry Process for Conversion of U-AVLIS Product to $\mathbf{U F}_{6}$}

Milestone U361

May 1992

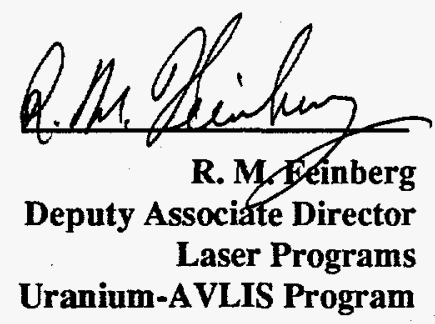

LAWRENCE LIVERMORE NATIONAL LABORATORY

University of California $•$ Livermore, California 994550

MARTIN MARIETTA ENERGY SYSTEMS

Oak Ridge, Tennessee $\bullet 37831$ 


\section{Contents}

Executive Summary ……..................................................................

1. Introduction

1.1 Objective

1.2 Approach of Study

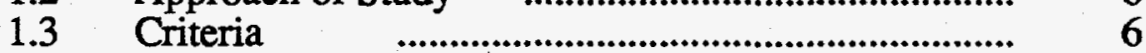

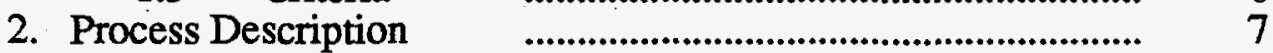

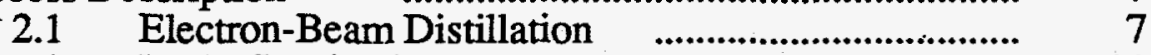

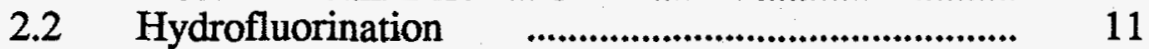

2.3 Fluorination …................................................. 13

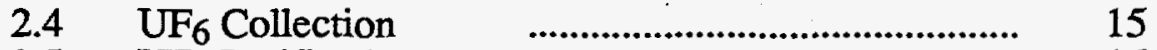

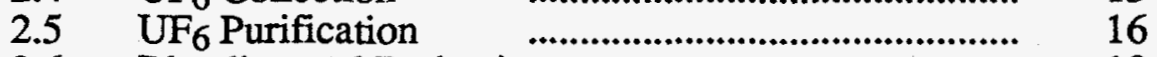

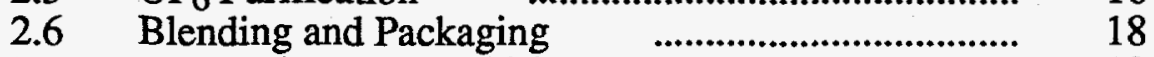

2.7 Conversion of Refurbishment Oxides $\quad$............ 19

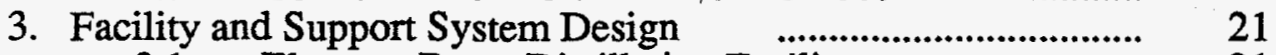

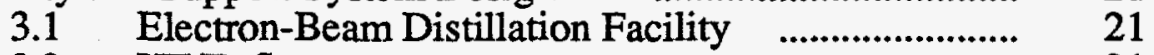

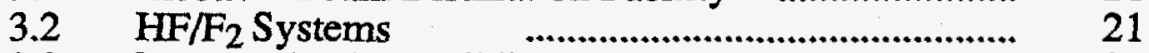

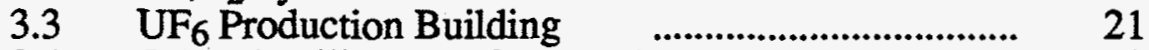

$3.4 \quad$ Other Auxiliary and Support Systems $\quad \ldots . . . . . . . \quad 22$

4. Capital and Operating Costs $\quad$............................................ 23

4.1 Capital Costs ............................................................ 23

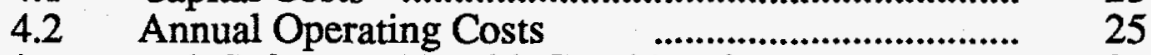

5. Environmental, Safety, and Health Considerations $\quad$............ 27

6. Development and Demonstration Requirements $\quad$........... 29

6.1 Recommended Development and Demonstration Activities $\quad$.......................................................... 29

6.2 Development and Demonstration Costs and

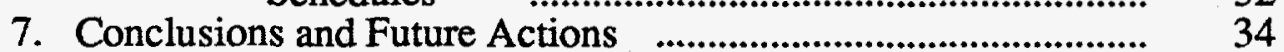

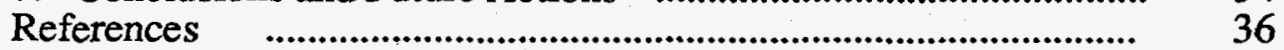

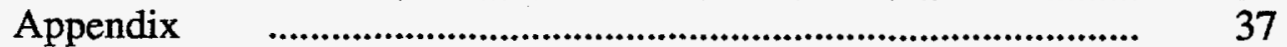

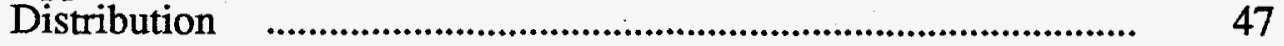




\section{Executive Summary}

A technical and engineering evaluation has been completed for a dry UF6 production system to convert the product of an initial two-line U-AVLIS plant. The objective of the study has been to develop a better understanding of process design requirements, capital and operating costs, and demonstration requirements for this alternate process. This report summarizes the results of the study and presents various comparisons between the baseline and alternate processes, building on the information contained in $U_{6}$ Product Alternatives Review Committee - Final Report (reference 1). It also provides additional information on flowsheet variations for the dry route which may warrant further consideration.

The information developed by this study and conceptual design information for the baseline process will be combined with information to be developed by the U-AVLIS program and by industrial participants over the next twelve months to permit a further comparison of the baseline and alternate processes in terms of cost, risk, and compatibility with U-AVLIS deployment schedules and strategies. This comparative information will be used to make a final process flowsheet selection for the initial U-AVLIS plant by March 1993 (Milestone U312).

The process studied is the alternate $\mathrm{UF}_{6}$ production flowsheet identified in reference 1. Process steps are (1) electron-beam distillation to reduce enriched product iron content from about $10 \mathrm{wt} \%$ to $1 \mathrm{wt} \%$ or less, (2) hydrofluorination of the metal to $U_{4}$, (3) fluorination of $U_{4}$ to $U_{6}$, (4) cold trap collection of the UF 6 product, (5) $U_{6}$ purification by distillation, and (6) final blending and packaging of the purified $\mathrm{UF}_{6}$ in cylinders. A preliminary system design has been prepared for the dry $\mathrm{UF}_{6}$ production process based on currently available technical information. For some process steps, such information is quite limited. Comparisons have been made between this alternate process and the baseline plant process for $\mathrm{UF}_{6}$ production. The baseline process employs acid dissolution of metal product, purification by solvent extraction, and $\mathrm{UO}_{3}$ production via modified direct denitration. One-third of the plant product is shipped in this form, and the remaining $\mathrm{UO}_{3}$ is directly fluorinated to produce $\mathrm{UF}_{6}$. The baseline process includes steps for $\mathrm{UF}_{6}$ collection and packaging that are the same as steps 4 and 6 described above for the dry process. For purposes of further comparison, conceptual design costs for this baseline system have been adjusted to create a "modified baseline" system which converts all of the enriched $\mathrm{UO}_{3}$ product to $\mathrm{UF}_{6}$, with none shipped in the intermediate $\mathrm{UO}_{3}$ form.

Results of this more detailed study confirm and support the comparative assessments made by the $\mathrm{UF}_{6}$ Product Alternatives Review Committee. Prior to presenting the more detailed information developed by the dry process study, a summary of this committee's comparative judgments is provided in Table 1.

Table 1

Summary comparison of the wet and dry processes based on principal discriminators

\begin{tabular}{|l|c|}
\hline \multicolumn{1}{|c|}{ Principal discriminator } & Process with advantage \\
\hline Technological maturity and industrial base & Wet \\
\hline Ability to meet deployment schedule & Wet \\
\hline Process simplicity/capital cost & Dry \\
\hline Process uncertainties and development costs & Wet \\
\hline Environmental, safety, and health issues & Neither \\
\hline Process flexibility (longer-term fuel cycle benefits) & Wet \\
\hline
\end{tabular}


Total estimated capital cost of the dry $U_{6}$ production system is $\$ 144$ million (current dollars), which compares with a capital cost of $\$ 189$ million for the baseline process and $\$ 197$ million for the modified baseline system. The dry process estimate is less detailed than the baseline process estimate and is based on a design that is substantially less mature than the conceptual design for the baseline process. Thus, the dry process estimate could be subject to greater cost change in subsequent design phases. Estimated annual operating costs for the dry process are $\$ 10$ million, including the cost for operating the supplemental uranium recovery system. Corresponding costs for the baseline and modified baseline processes are $\$ 11$ and $\$ 12$ million, respectively.

Development and demonstration requirements for the dry process are judged to be greatest for the electron-beam distillation and hydrofluorination steps. Laboratory scale, engineering scale, and prototype scale work are all recommended for the hydrofluorination process. Electron-beam distillation system prototype testing should be done in concert with the required work for the separator product recast system, which could heavily subsidize the dry path system's needs in this area. Laboratory experiments are required to obtain data for distillation system design, with the need for larger scale activities for this step to be determined based on the laboratory data.

The total incremental cost for recommended development and demonstration work for the dry process is $\$ 23$ million. Incremental costs exclude program management, costs for building space, and other fixed costs. These estimated costs are preliminary and are based on the work being performed at locations that remain to be determined. The site for the work is assumed to have an existing infrastructure for safe handling and management of $F_{2}, \mathrm{HF}, \mathrm{UF}_{6}$, and costs will be higher if this requirement is not satisfied. Nothing is included in these costs at present for electron-beam distillation demonstration activities. It is anticipated that the separator recasting development and demonstration effort will provide an estimated $\$ 10$ million in mutually beneficial data. Also, costs are included only for laboratory scale $\mathrm{UF}_{6}$ distillation experiments, although additional larger scale work may be required.

The corresponding total incremental demonstration cost for the baseline wet process is $\$ 20$ million, of which $\$ 13$ million directly supports non-fluoride based processing of AVLIS product and the associated avoidance of the safety hazards, wastes, and added costs of a UF 6 product form. The demonstration requirements and associated costs for the baseline process have gone through several years of evaluation and refinement and are known to a higher degree of certainty than the corresponding information for the dry process.

The schedule for completing the recommended demonstration work for the dry process is estimated to require 4-5 years. Based on the current project schedule (design start in mid-FY1993), laboratozy and engineering scale data could be available during Title II design, with prototype testing accomplished in parallel with the completion of Title II design. In comparison present demonstration plans for the baseline process will result in data required to support initial plant deployment being available early in Title II design. Also, schedule uncertainty for the dry path demonstration work is greater than for the work supporting the baseline process due to current unknowns about scope and method of accomplishment.

Several alternative flowsheets for dry $\mathrm{UF}_{6}$ production may have merit and could be given further consideration. Of particular interest is elimination of the electron-beam distillation step to avoid its sigrificant uranium losses. To determine the feasibility of eliminating this step, additional information would be needed beyond that required for the dry path flowsheet evaluated in this study. This additional information includes the effects of full iron content on the metal hydrofluorination step and the feasibility and cost of a modified fluorination reactor system which incorporates on-line removal and recycle of bed diluent to manage the rapid buildup of $\mathrm{FeF}_{3}$. Such a reactor design would likely require prototype testing. 
Another flowsheet alternative which should be regarded as a backup approach involves metal oxidation prior to hydrofluorination (or prior to direct fluorination). There is production experience with hydrofluorination and fluorination of uranium oxides, and the oxidation step could be added if initial work on metal hydrofluorination identifies any basic problems.

It is recommended that current activities in support of the baseline product conversion process continue as planned. In parallel, plans should proceed to contract with qualified industrial firms to evaluate the conceptual design of the baseline process and the dry process design prepared in this study. These evaluations will provide an industrial perspective and establish a further basis for deciding what experimental work is warranted for the dry process. In addition, the following actions are suggested:

- Perform additional trade-off studies to determine if dry process flowsheet modifications, such as elimination of electron-beam distillation and/or replacement of hydrofluorination with air or steam oxidation, offer advantages such as reduced production costs or reduced demonstration needs.

- Establish options for carrying out prototype scale experiments involving fluorine bearing chemicals and $\mathrm{UF}_{6}$ and define associated facility costs for these demonstrations. 


\section{Introduction}

A UF6 product form is recommended for the initial two-line U-AVLIS production plant to minimize the impact of market entry on utilities and fuel fabricators. The wet process is the baseline $\mathrm{UF}_{6}$ production process for initial deployment. This process employs metal dissolution, solvent extraction, and modified direct denitration to produce an intermediate pure $\mathrm{UO}_{3}$ product. One-third of the plant product is assumed to be shipped as $\mathrm{UO}_{3}$, and the remainder is directly fluorinated to produce $\mathrm{UF}_{6}$.

The reasons for selection of this process as the baseline for the initial U-AVLIS plant are presented in $U F_{6}$ Product Alternatives Review Committee - Final Report (reference 1). The design requirements for this baseline procèss have been well characterized and are described in detail in several volumes of $U$-AVLIS Production Plant Conceptual Design Report (reference 2).

The review of $\mathrm{UF}_{6}$ product alternatives identified a second primary candidate process for production of $\mathrm{UF}_{6}$. It is referred to as the "dry" process since it does not employ the aqueous chemical purification steps used in the baseline flowsheet. This alternate process was selected from several variations of the dry pathway, which are shown in Figure 1. The highlighted process represents the selected alternative. Its key steps are partial removal of iron by electron-beam distillation, hydrofluorination of the partially purified product alloy to $\mathrm{UF}_{4}$, fluorination of the $\mathrm{UF}_{4}$ to $\mathrm{UF}_{6}$, and fractional distillation of the $\mathrm{UF}_{6}$ to remove high and low boiling volatile impurities.

The review concluded that this dry process offers the advantages of process simplicity and therefore expected cost savings. It also concluded that the existing technical data base and industrial experience are not sufficient to support the design, with acceptable risk, of an AVLIS-specific dry conversion route to $\mathrm{UF}_{6}$. Thus, a significant development/demonstration effort would be necessary before proceeding with a plant design based on the dry pathway.

\subsection{Objective}

As recommended by the $\mathrm{UF}_{6}$ Product Alternatives Review Committee, a more detailed technical and engineering study of the dry $\mathrm{UF}_{6}$ production process has been performed. The objective of the study has been to develop a better understanding of process design requirements, capital and operating costs, and demonstration requirements for this alternate process. This report summarizes the results of the study and presents various comparisons between the baseline and alternate processes, building on the information contained in the committee's final report. It also provides additional information on flowsheet variations for the dry route which may warrant further consideration.

The information developed by this study and conceptual design information for the baseline process will be combined with information to be developed by the U-AVLIS program and by industrial participants over the next twelve months to permit a further comparison of the baseline and alternate processes in terms of cost, risk, and compatibility with U-AVLIS deployment schedules and strategies. This comparative information will be used to make a final process flowsheet selection for the initial U-AVLIS plant by March 1993 (Milestone U312). 


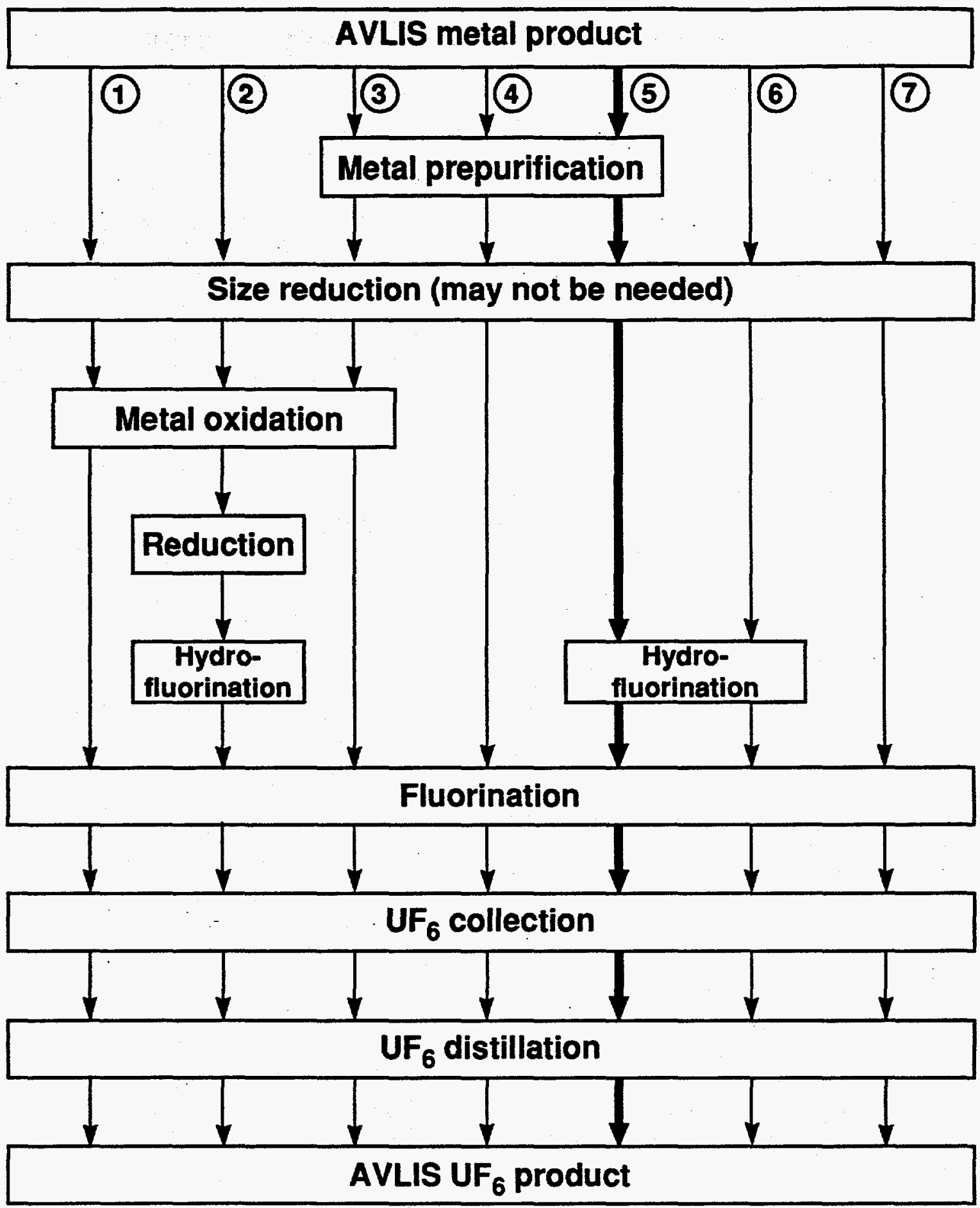

Figure 1. Alternatives for dry UF6 production flowsheet. Flowsheet selected for study is highlighted. 


\subsection{Study Approach}

The technical requirements of each step in the dry $\mathrm{UF}_{6}$ production process were first examined. Existing data applicable to each step were identified, and analyses of process chemistry were accomplished to establish additional data where required. Using this information, a preliminary engineering design for the system was then developed, and from this design capital and operating costs for the system were generated. The engineering design included the following:

- Process flowsheet development

- Equipment design concepts

- Preliminary facility layouts

- Waste stream characterizations

An approach to engineering design and cost estimation consistent with that used for the plant conceptual design was maintained. Wherever possible, specific equipment and subsystem designs and costs developed for the baseline $\mathrm{UO}_{3} / \mathrm{UF}_{6}$ product system conceptual design were used. Such information was directly applicable to significant portions of the dry process system.

Concurrent with engineering design work, an assessment was made of technical uncertainties and demonstration costs and schedules. When assessing demonstration schedules, it was assumed that funds would be available as needed.

While appropriate comparisons are made in this report between the baseline and alternate processes, no attempt is made to reach a final judgment as to whether a change in the baseline flowsheet is justified. Planned follow-on work is expected to provide additional information for use in making the flowsheet selection.

\subsection{Criteria}

The engineering design for the dry $\mathrm{UF}_{6}$ production system is based on the initial UAVLIS plant criteria given in U-AVLIS Two-Separator Module Production Plant Primary Criteria (reference 3). However, while these criteria call for shipment of one-third of the plant's product as $\mathrm{UO}_{3}$ and the remainder as $\mathrm{UF}_{6}$, the dry $\mathrm{UF}_{6}$ production system is only capable of producing UF6. Enriched product output is nominally $600,000 \mathrm{kgU} / \mathrm{y}$. All uranium processing equipment and subsystems must be designed for nuclear criticality safety for isotopic assays up to $5 \mathrm{wt} \% 235 \mathrm{U}$. Purity requirements for the final $\mathrm{UF}_{6}$ product are given in reference 3 and are based on current industry specifications, although specific limits for certain impurities that may be important for U-AVLIS product are not contained in the industry specification.

The final output from the dry $\mathrm{UF}_{6}$ production system is blended UF 6 meeting customer isotopic assay requirements and packaged in 10-ton cylinders. Final sampling and transfer into fuel fabricator-owned cylinders is accomplished at existing GDP facilities, similar to plans established for the baseline system.

Enriched metal product at several isotopic assays is produced by the separator system and transferred to the dry $\mathrm{UF}_{6}$ production system for conversion. Parallel process lines allowing concurrent processing of multiple streams are not required since campaign operations can be employed to convert product at different isotopic levels. Accumulation capacity is required to permit isotopic blending during cylinder filling. This is also consistent with plans established for the baseline system. 


\section{Process' Description}

This section presents a technical description of each of the major process steps in the dry $\mathrm{UF}_{6}$ production system. The technology basis for the engineering design is presented, and key parameters for the major pieces of process equipment are identified. Advantages and disadvantages of including each step in the dry $\mathrm{UF}_{6}$ production system and alternate approaches are discussed, where applicable.

The selected flow sheet is summarized in Figure 2. It involves the following key steps: (1) electron-beam distillation to produce uranium metal containing $1 \mathrm{wt} \%$ iron or less, (2) hydrofluorination to $\mathrm{UF}_{4}$ in the presence of hydrogen gas, (3) fluorination with elemental fluorine to produce $\mathrm{UF}_{6}$, (4) collection of $\mathrm{UF}_{6}$ product by cold trapping, (5) removal of trace volatile impurities by fractional distillation supplemented, as required, by sorption and sublimation, and 6) blending to required customer assays and packaging in shipping cylinders.

Process flowsheets developed during the study are included in this report as Appendix A. These provide additional information on most of the major process steps described in this section. In some cases, details shown on these flow sheets (such as the number of some equipment units) were revised during completion of the capital cost estimate for the system. These changes are identified at the beginning of Appendix A.

\subsection{Electron-Beam Distillation}

Enriched product is withdrawn from AVLIS uranium separators in the form of uranium/iron alloy disks or splats. The alloy has an iron content of approximately 10 wt \%. Electron-beam metal distillation is employed to reduce this value to $1 \mathrm{wt} \%$ or less prior to hydrofluorination.

\subsubsection{Process Advantages and Disadvantages}

Reduction of iron content in the enriched metal product by an order of magnitude prior to chemical conversion has the advantages of reducing reactant consumption in the hydrofluorination and fluorination steps and increasing bed life in the fluorination reactors where the non-volatile iron fluoride $\left(\mathrm{FeF}_{3}\right)$ produced during these steps accumulates. Increased bed life reduces the generation rate of uranium-contaminated $\mathrm{CaF}_{2} / \mathrm{FeF}_{3}$ waste and reduces the required number of reactors due to reduced down-time for bed change-out. Lower iron content may also improve the kinetics of the hydrofluorination reaction and thus may also reduce the number of required hydrofluorination reactors.

Disadvantages of including the prepurification step are its capital and operating costs and the carry over of a small but significant portion of enriched uranium product with the iron distillate. The value of the uranium contained in the reject stream is sufficient to justify investing in equipment for its recovery.

\subsubsection{Technology Basis}

Electron-beam distillation is used in industry to remove impurities from metals. Although the method has not been used commercially for uranium purification, the proposed application is technically feasible due to the much greater volatility $(300 \mathrm{x})$ of pure iron compared to pure uranium at elevated temperatures. Industrial experience and hardware designs from other applications together with the experience with uranium/iron systems gained through AVLIS vapor source development provide a sound technology base for this proposed use. 


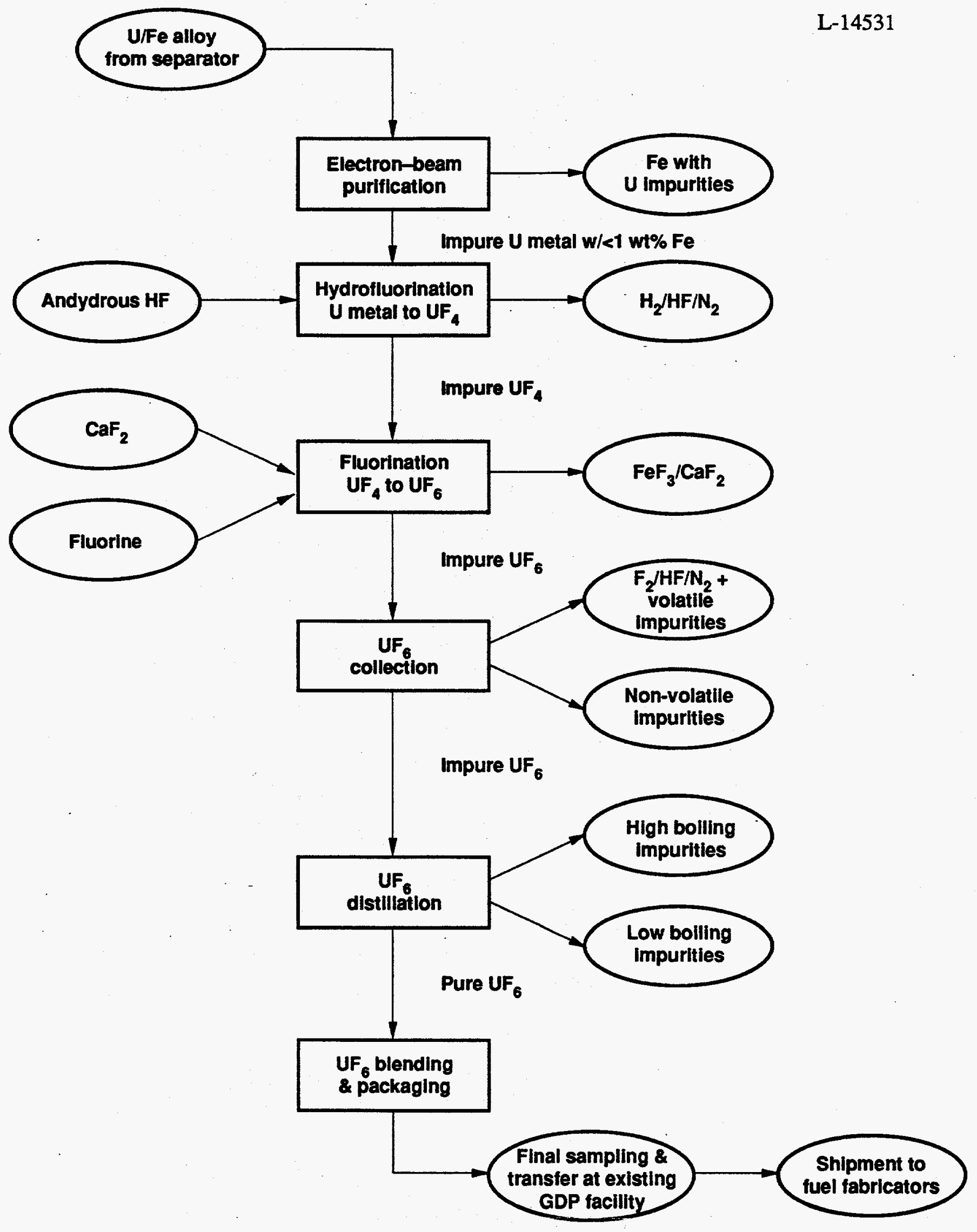

Figure 2. Flow diagram for dry $\mathrm{UF}_{6}$ production system. 
The plan to employ electron-beam distillation within the uranium separator system to permit staging of separator product increases its attractiveness for prepurification of separator product prior to dry UF6 production. In the separator product recast system, iron content is reduced from approximately 10 to $3 \mathrm{wt} \%$, and the resulting alloy is cast into separator feed rods. For final product prepurification, an iron reduction from 10 to $1 \mathrm{wt} \%$ is the target established for this study, and the resulting material is cast into small splats for transfer to the dry $\mathrm{UF}_{6}$ production system. Despite these differences, the functions are similar, and the costs of demonstration, design, and operation can be shared. The attractiveness of including this step in the dry UF6 process flowsheet would be diminished if this cost-sharing were not possible. [Note: It is assumed that these two applications of electron-beam distillation cannot be performed using the same plant hardware for reasons of nuclear criticality safety and nuclear materials safeguards. Use of separate dedicated hardware will reduce or eliminate the administrative controls that would be required if enriched product at or near assays of $5 \mathrm{wt} \% 235 \mathrm{U}$ were routinely fed to a system capable in its alternate configuration of producing separator feed rods.]

\subsubsection{System Description}

The electron-beam distillation system for product prepurification is based on a hardware design that is similar to that included in the conceptual design of the separator product recast system. Enriched alloy splats are continuously fed to one end of a $140 \mathrm{~cm}$ long $\times 10 \mathrm{~cm}$ wide crucible at the rate of about $100 \mathrm{kgU} / \mathrm{h}$. Under the action of two $400 \mathrm{~kW}$ electron beams, each with a dimension of $65 \mathrm{~cm} \mathrm{x} 2 \mathrm{~cm}$, the alloy is melted and raised to a temperature exceeding $2000 \mathrm{C}$. The operation takes place within a stainless steel vessel maintained at an operating pressure of about $10^{-4}$ Torr.

As the molten uranium-iron alloy flows along the length of the crucible, the iron is preferentially vaporized. Based on slow axial mixing, the iron vapor rate falls off exponentially with distance from the alloy feed end, while the uranium vapor rate is nearly constant over the entire pool length. The iron-uranium distillate is collected as a solid on elements above the crucible.

The purified molten uranium product stream, with iron content of about $1 \mathrm{wt} \%$, flows out the opposite end of the crucible and is cast as small splats using a splat casting mechanism like that used for withdrawal stream casting within separator pods. The splats are collected in a cylindrical canister, and after sampling and weighing for nuclear material accountability, are transferred to the $\mathrm{UF}_{6}$ production system.

Figure 3 is a simple flow sheet for the system, showing annual flows of uranium and iron. As depicted in the figure, the iron-uranium distillate is collected at two positions, with the higher-uranium-containing distillate from the downstream half of the crucible refed to the system. The distillate from the upstream portion of the crucible with a uranium concentration of about $7 \mathrm{wt} \%$ is packaged for transfer to a uranium recovery system for further processing. Uranium content of this stream is estimated to be about $4,200 \mathrm{kgU} / \mathrm{y}$ or about $0.7 \%$ of uranium product throughput. The actual loss rate will be determined by test operations. Based on the estimated uranium content along with values of $\$ 70 / \mathrm{SWU}$, $\$ 60 / \mathrm{kg}$ natural uranium, and $0.25 \mathrm{wt} \% 235 \mathrm{U}$ transaction tails assay, the value of this stream is approximately $\$ 3$ million $/ y$.

\subsubsection{Alternatives}

Alternatives to the described system fall into the following categories: (1) design optimization to reduce uranium carry-over into the distillate without substantial reduction in the iron removal factor, (2) sclection of a different prepurification method, and (3) elimination of this process step. 


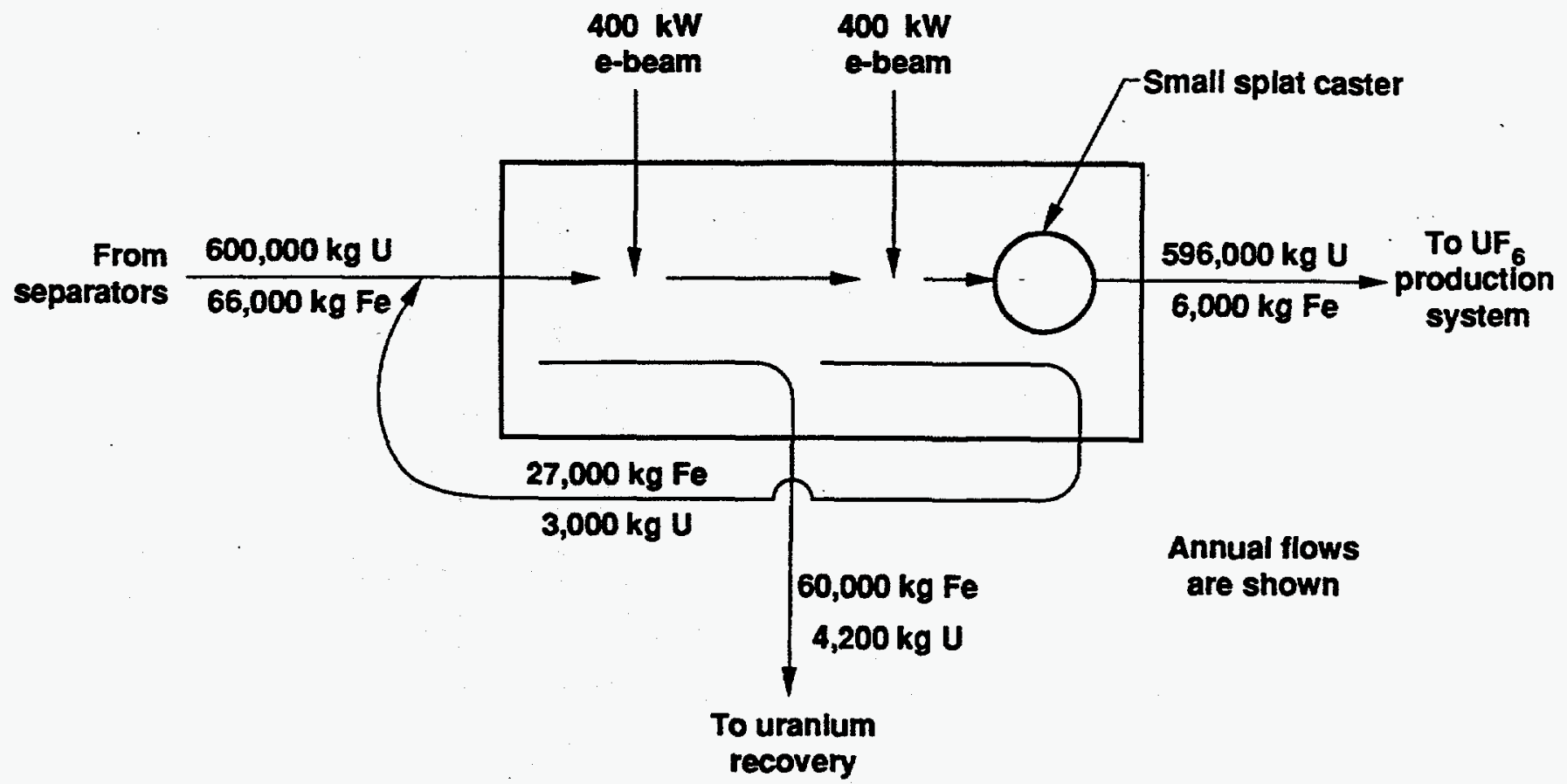

Figure 3. Steady-state flow diagram for electron-beam distillation system.

Design optimization to reduce uranium carry-over while maintaining a ten-fold iron reduction would provide substantial economic benefits. This might be achievable by increasing the length of the crucible and substantially increasing the alloy flow rate along its length. Reduction of uranium carry-over to a range of 0.3 to $0.5 \%$ is theoretically possible, with an increase in system capital cost and a decrease in the number of hours of required system operation. Also, the greater the degree of optimization sought, the greater the cost of demonstration testing to establish practical control methods.

Possible alternatives to electron-beam distillation for product prepurification include magnetic separation (probably after oxidation) and electrorefining, which would also eliminate other impurities and possibly reduce the need to distill UF6 product. Nonaqueous pyroprocessing methods might also be considered. No technical effort was made to evaluate these alternatives during this study, but earlier studies identified a limited data base which could be used to evaluate the technical feasibility of these options.

Elimination of the prepurification step is an option that is worth further consideration. Since this action would certainly affect design and operation of the fluorination step, it is discussed along with that process step. Effects on the hydrofluorination step are also likely, but additional data are needed to determine their nature and extent. 


\subsection{Hydrofluorination}

The partially purified uranium metal is reacted with gaseous anhydrous hydrogen fluoride (AHF) in a mixture with hydrogen gas. The hydrogen attacks the metal to form uranium hydride $\left(\mathrm{UH}_{3}\right)$ which then reacts rapidly with the $\mathrm{AHF}$, producing uranium tetrafluoride (UF4) and byproduct hydrogen.

\subsubsection{Advantages and Disadvantages}

Conversion of the uranium metal to $\mathrm{UF}_{4}$ uses HF rather than the more expensive fluorine to provide $2 / 3$ of the fluoride necessary to make $\mathrm{UF}_{6}$. The hydrofluorination step is expected to allow relatively easy reaction control and provide a more readily fluorinated product powder with lessened heat removal and reaction control problems in the subsequent fluorination step. The primary disadvantage is the requirement for hydrogen and $\mathrm{HF}$ recycle systems.

\subsubsection{Technology Basis}

The limited data on uranium metal hydrofluorination from the bench-scale work performed in 1942-43 at the Ames Laboratory is discussed in reference 1. Although useful in establishing a preliminary design within this study, this early work is insufficient for designing and specifying the operating characteristics of a practical chemical reactor for conversion of AVLIS enriched metal.

The Ames work showed that the conversion will occur at relatively low temperatures ( 250 to $400 \mathrm{C}$ ), producing $\mathrm{UF}_{4}$ product of good quality. The rate increases if the reacting metal is vibrated to remove the UF 4 coating. The limited thermal stability of $\mathrm{UH}_{3}$ has a thermostatting effect on the reaction because the hydride decomposes back to its elemental components at about $400 \mathrm{C}$. The reaction rate is on the order of $2.9 \mathrm{gU} / \mathrm{h} / \mathrm{cm}^{2}$, which corresponds to a penetration rate of $0.16 \mathrm{~cm} / \mathrm{h}$. The preferred gas mixture is about $50 \%$ hydrogen and $50 \% \mathrm{HF}$.

The Ames experiments used pure uranium metal that had been cleaned by acid etching. The presence of iron and other impurities, oxide coatings, or surface nitriding must be considered for the AVLIS application. Impurities may not react well with the AHF if they do not first hydride. Iron, aluminum, chromium, and tungsten are examples of nonhydriding elements. The kinetics of the reaction for uranium-iron alloys with $\mathrm{HF}$ at varying iron concentrations have not been established.

\subsubsection{System Description}

Partially purified metal received from the electron-beam distillation system in the form of small splats is unloaded into a feed hopper system prior to feeding to the hydrofluorination reactor. The reaction is carried out in a vertical pipe reactor which is provided with internal baffle shelves to hold the reacting metal pieces and improve heat transfer and gas flow. The shelves are perforated to allow UF4 powder to drop through. The reactor is vibrated to move the metal from shelf to shelf while at the same time dislodging the $\mathrm{UF}_{4}$ scale to expedite the reaction. The recycle gas feed point is in the upper, heated $(275 \mathrm{C})$ section of the reactor. The downflowing gas which is higher in hydrogen content initiates the hydriding reaction. The makeup AHF is introduced part way down the reactor to provide the main reaction. The heat of reaction is removed by air cooling the finned outer surface of the reactor, maintaining a uniform operating temperature of $275 \mathrm{C}$ along the entire length of the reactor. Since the hydriding reaction stops at about $425 \mathrm{C}$ (with concurrent decrease in hydrofluorination), the possibility of temperature overshoot is minimal. 
Four reactors are required, each with a projected design capacity of $27 \mathrm{kgU} / \mathrm{h}$. This results in a product rate per reactor of $35 \mathrm{kgUF}_{4} / \mathrm{h}$. Two hours residence time is provided. At the design impurity concentration of $1 \mathrm{wt} \%$ iron, $0.45 \mathrm{~kg} / \mathrm{h}$ of ferrous fluoride $\left(\mathrm{FeF}_{2}\right)$ is formed. The reactors have an 8-in internal diameter, which is based on geometrical limits for reasons of nuclear criticality safety, and they are about $17 \mathrm{ft}$ in overall height. The reactor is made of monel with nickel shelves and fins. A preliminary design drawing of the hydrofluorination reactor is included with the process flow sheets in the Appendix.

The product $\mathrm{UF}_{4}$ is removed at the bottom of the reactor and conveyed to the fluorination system. The exit gases are passed through two filters in series, with the solids collected in the primary filter returned to the product hopper. Monel porous metal filter tubes are used.

Gases exiting the filter system flow to a recycle system which is common to the four reactor lines. There the gases are cooled and a portion recycled directly to the reactors. The remainder is passed through a condenser system for AHF recovery and then through a burner to eliminate byproduct hydrogen produced in the reaction. The burned gases are scrubbed with water to eliminate small amounts of HF and then vented. The recovered AHF is vaporized and combined with fresh AHF to feed the reactors. A local day tank which receives AHF from the main storage area supplies the fresh AHF to replace that consumed in the reaction and lost to the scrubber.

\subsubsection{Alternatives}

In addition to the reactor concept chosen here, other types of reactors such as rotary kilns, vibrating trays, or fluidized beds might be considered.

If the hydrofluorination concept is found to be ineffective, oxidation approaches are available to prepare the metal for hydrofluorination or direct fluorination. Use of steam in the presence of hydrogen should allow production of $\mathrm{UO}_{2}$ in a reactor system very similar to that above, although the kinetics with $1 \%$ iron present are uncertain. Likewise air would oxidize metal at a somewhat higher temperature to produce $\mathrm{U}_{3} \mathrm{O}_{8}$, with less uncertainty about kinetics as a result of data on AVLIS alloy product oxidation obtained at Oak Ridge (K-25) in 1984 and 1985.

Both reduction of uranium oxide to $\mathrm{UO}_{2}$ and hydrofluorination of $\mathrm{UO}_{2}$ to produce $\mathrm{UF}_{4}$ are employed in industry and present little technical risk. There may, however, be some uncertainty as to quality of the UF 4 produced due to starting material characteristics. Both hydrogen reduction and kydrofluorination produce water as a byproduct. In the case of the hydrofluorination, dilute hydrofluoric acid is produced. Production of $\mathrm{UF}_{4}$ by direct conversion of metal with HF is in principle a much simpler and lower waste generating route.

Direct fluorination of uranium oxide to $\mathrm{UF}_{6}$ is the more straightforward route as compared to first converting the oxide to $\mathrm{UF}_{4}$ but (1) three times as much fluorine is required and (2) fluorination reactor capacities are reduced due to heat transfer limitations. On balance, however, for AVLIS product assays and throughputs, direct fluorination of oxide would be preferred over reduction-hydrofluorination of oxide because of fewer steps, waste reduction, and less complicated operations. Therefore, direct fluorination of oxide is used in the baseline wet UF6 production process.

The final alternative is to directly fluorinate the alloy. Not only is this step technically undeveloped but it also requires as much fluorine as does direct fluorination of oxide and has the highest heat removal requirements coupled with a relatively low melting feed material. 


\subsection{Fluorination}

The $\mathrm{UF}_{4}$ produced in the previous step is reacted with elemental fluorine $\left(\mathrm{F}_{2}\right)$ in a fluid-bed reactor to produce $\mathrm{UF}_{6}$. A bed diluent such as fluorspar $\left(\mathrm{CaF}_{2}\right)$ or magnesium fluoride $\left(\mathrm{MgF}_{2}\right)$ is used to disperse the reaction for heat control and inventory purposes. $\mathrm{CaF}_{2}$ has been selected as the bed diluent for the purposes of this study.

\subsubsection{Advantages and Disadvantages}

The fluorination step is required for $\mathrm{UF}_{6}$ production under all variations of the dry path flowsheet considered to date. Thus, the key process trades associated with this step are related to the steps performed prior to fluorination and their net effects. The chemical form of the uranium product delivered for fluorination ( $\mathrm{UF}_{4}$, metal, or oxide), its iron content, and its physical form (particle size, etc.) define the requirements for the fluorination system.

Reduction of iron content and preconversion of the uranium to $\mathrm{UF}_{4}$ both reduce fluorine requirements and heat transfer removal problems in the fluorinator. Additionally lower iron content reduces the bed waste generation rates that are required to purge the nonvolatile iron fluorides from the system. The costs of the prepurification and hydrofluorination steps are paid to achieve these benefits.

\subsubsection{Technology Basis}

There is a broad industrial base for fluorination of $\mathrm{UF}_{4}$ having low iron content. The process is used by industry for natural assay $\mathrm{UF}_{6}$ production, but has not been applied on a large scale for the fluorination of enriched uranium at assays up to $5 \mathrm{wt} \%$. Therefore, equipment size limitations due to nuclear criticality safety requirements present some design uncertainties. In addition, the 1\% iron level of the AVLIS product may represent the upper limit of the industrial experience base; ASTM specification C967-87 for uranium ore concentrate to be converted to $\mathrm{UF}_{6}$ indicates a penalty at iron levels $>0.15 \mathrm{wt} \%$ and rejection at iron levels $>1 \mathrm{wt} \%$, unless otherwise agreed to between buyer and seller (reference 4).

The level of technical uncertainty would be greater for fluorination of $\mathrm{UF}_{4}$ produced from metal with high iron content (about $10 \mathrm{wt} \%$ ) and for fluorination of metal. There is a lack of experimental data and production scale experience with fluorination of these materials.

\subsubsection{System Description}

$\mathrm{UF}_{4}$ produced in the hydrofluorination step is fed from an intermediate hopper system into one of four fluorination reactors. Screening of the UFF 4 to control particle size may be needed prior to feeding to the reactor. Within the fluidized bed of diluent, the UF 4 reacts with diluted fluorine gas introduced into the cone bottom of the reactor. The reactors are designed in essentially the same manner as the fluorination reactors included in the conceptual design for the plant baseline UF6 production system. They have internal diameters of 10 inches. The bed operating temperature is maintained at about $500 \mathrm{C}$, and the uranium content of the bed is nominally $5 \mathrm{wt} \%$ during steady-state operation. Reaction heat is removed by air flowing in an annulus around the finned reactor. The reactor is constructed of either monel or nickel, with nickel external fins. Copper may be used in lower temperature locations.

Elements such as tungsten, niobium, molybdenum, vanadium, tantalum, silicon, and chromium form volatile fluorides and accompany the $\mathrm{UF}_{6}$ in the reactor product gas. Others such as iron, nickel, alkali metals, and thorium form non-volatile fluorides and accumulate in the bed. If allowed to accumulate in excessive amounts, these compounds may interfere with reactor operation. Also, some otherwise volatile fluorides may not be 
volatilized due to sorption on the bed diluent. Thus, it is necessary to periodically replace the bed diluent to prevent such excessive accumulation. If impurities that form non-volatile fluorides were sufficiently eliminated from the UF4 feedstock, other reasons for periodic bed replacement would be accumulation of radioactive uranium daughter products (such as 234 $\mathrm{Th}$ ) and diluent particle size deterioration to the point that fluidization characteristics are affected. In this study, iron fluoride accumulation is judged to be the governing effect, and it has been assumed that the bed should be replaced when the iron content reaches $8 \mathrm{wt} \%$ (that is, when the $\mathrm{FeF}_{3}$ content reaches about $16 \mathrm{wt} \%$ ). Prior to dumping the bed to the waste handling system an exhaustive fluorination is carried out to reduce its uranium content to about $0.1 \mathrm{wt} \%$.

The quantity of diluent in a fresh charge is $70 \mathrm{~kg}$, and the fluid bed is initially $4 \mathrm{ft}$ deep in the 10-inch diameter reactor. Four feet of height is provided above the top of the bed to provide space for the accumulation of the non-volatile impurity fluorides and to allow gas cooling before filtration in the primary filter which is mounted in the top part of the reactor shell. Solids are periodically dislodged from the filter by reverse flow of nitrogen or dry air and fall back into the reactor. A second external filter is used to ensure complete removal of solids. Porous metal tubes made of monel or nickel are used for filtration. The filtered gases then flow to the $\mathrm{UF}_{6}$ collection system for $\mathrm{UF}_{6}$ recovery and gas handling.

After accumulation of about $13 \mathrm{~kg}$ of ferric fluoride $\left(\mathrm{FeF}_{3}\right)$, the $\mathrm{UF}_{4}$ feed stream is interrupted and fluorination is continued to strip the uranium from the bed. The bed is then isolated from the recycle stream, purged with nitrogen and drained from the reactor. A conveyor moves the bed material to an area for cooling, sampling, and waste packaging. Fresh diluent is loaded into the reactor which can then be placed back on stream.

Bed clean-up and changeout will be required after about $24 \mathrm{~h}$ of steady-state reactor operation. The total period that $\mathrm{UF}_{4}$ feed to the reactor is stopped for bed clean-up and replacement is approximately $8 \mathrm{~h}$. During this period, the hydrofluorination process can continue in the associated hydrofluorination reactor, with $\mathrm{UF}_{4}$ allowed to accumulate in the intermediate feed hopper.

\subsubsection{Alternatives}

There are two categories of alternatives for this process step: (1) alternate methods of fluorinating the feedstock chosen (UF4 with iron content of about $1 \mathrm{wt} \%$ on a $\mathrm{U}$ basis) and (2) alternate methods involving a different feed form.

The baseline $\mathrm{UF}_{4}$ feedstock (or an oxide feed form) could be fluorinated in a flame tower reactor. This simple reactor design was not chosen for this study because from 2 $5 \%$ of the feed is not fluorinated in the first pass down the reactor and must be ground and refed into the top. In addition flame tower reactors are subject to more operating problems with impure feeds due to wall slagging. The fluid bed design also offers some advantage in managing radioactive daughter products because the bed material will both dilute them and aid in their movement. In flame tower systems, these contaminants tend to build up in the recycled material and can only be removed from the cycle by sacrificing uranium product.

A stirred bed reactor concept, similar to stirred bed hydrofluorination which was utilized at Paducah and which is in use in the commercial UF 6 industry, might be used in the fluorination step to overcome possible bed fluidization difficulties and to allow operation with higher levels of impurity accumulation.

Among alternate methods involving a different feed form, fluorination of UF 4 with high iron content is of particular interest. A two-step fluorination system might be used to achieve continuous operation even in the presence of iron at levels up to the nominal product concentration of $10 \mathrm{wt} \%$. In this approach a fluid bed reactor is used for the main fluorination reaction, with impurities removed by diluent blow-over (elutriation) to an external collector or by on-line draining from the reactor bottom. This uranium-bearing stream is processed in a screw reactor in which a counter-current stream of fluorine strips 
the uranium from the diluent to discard levels and returns the gas flow to the main reactor discharge. Although this approach requires a more complicated reactor system in each line, the number of lines can be reduced because of the system's ability to operate continuously. The usage of bed diluent may be increased depending on the ability to separate it from the iron fluoride by elutriation.

Direct fluorination of metal is a possibility with a primary drawback being consumption of three times the elemental fluorine needed for fluorination of $\mathrm{UF}_{4}$. The higher heat of reaction also limits the throughput of a single reactor of constrained geometry due to equipment heat transfer limitations. This leads to a larger number of fluorination reactors, likely offsetting the possible cost benefits of eliminating hydrofluorination equipment.

\subsection{Product Collection}

Cold trapping is used to remove and collect the $\mathrm{UF}_{6}$ from the gas stream exiting the fluorination reactors. A portion of cold trap off-gases is recycled to the fluorination reactors, and the remainder is treated for removal of fluorides and residual uranium prior to atmospheric discharge.

\subsubsection{Advantages and Disadvantages}

The $\mathrm{UF}_{6}$ collection step is required for each of the alternative dry $\mathrm{UF}_{6}$ production flowsheets. The advantages and disadvantages of the selected method are discussed in section 2.4.4 in the context of the alternate collection method evaluated in the study.

\subsubsection{Technology Basis}

Cold trapping is a conventional technology that is used commercially for UF6 collection. A specific trap design optimized for use with uranium at assays up to $5 \mathrm{wt} \%$ does not exist, but there is adequate basis for developing such a design.

\subsubsection{System Description}

The UF 6 collection system applied to the dry $\mathrm{UF}_{6}$ production system is essentially the same as the system included in the conceptual design of the baseline UF6 product system, differing only in the quantity of equipment.

The gas stream exiting the fluorination reactor contains about $15-30 \% \mathrm{UF}_{6}$ and $5-15 \% \mathrm{~F}_{2}$. The remainder is nitrogen and oxygen, with a small amount of HF. The UF6 is collected by desublimation in primary cold traps operated with a refrigerant temperature of $-40 \mathrm{C}$. The saturation temperature of the exit gas is $-30 \mathrm{C}$. Upon completion of the loading cycle, a trap is isolated from the gas flow and heated to about $75 \mathrm{C}$ to melt the $\mathrm{UF}_{6}$. Its liquid contents are then drained into a receiver for distillation.

The gas exiting the primary trap, which contains about $2 \% \mathrm{UF}_{6}$, is compressed and part is combined with makeup $\mathrm{F}_{2}$ and returned to the fluorination reactor where it is used as the fluidizing gas. The remainder is diverted to a secondary cold trap system operated with a refrigerant temperature of $-80 \mathrm{C}$ where almost all of the residual $\mathrm{UF}_{6}$ is removed. Off-gas from the secondary trap flows to an off-gas treatment system for removal of fluorides and trace uranium prior to venting. When a secondary cold trap is filled, it is heated, burped to a sodium fluoride trap for HF removal, if required, and then heated further to vaporize its UF' contents which flow back to a primary trap for collection. 
Primary cold traps are 10 inches in diameter and about $25 \mathrm{ft}$ long. The active trapping section is $20 \mathrm{ft}$ in length with a trapping volume of approximately $5.6 \mathrm{ft}^{3}$ per trap. Trap capacity is $320 \mathrm{~kg} \mathrm{UF}_{6}$. The heat exchange section is fabricated externally by attaching plate fins to double-walled coolant tubes in a U-tube configuration. The spacing is selected to prevent premature plugging by the desublimed UF6. The heat transfer core is inserted into the cold trap shell and welded in place at one end. Secondary traps are similarly fabricated. Monel, nickel, and copper are typical materials of construction.

A typical primary cold trap cycle consists of $8 \mathrm{~h}$ of trapping, $8 \mathrm{~h}$ of heating and draining, and $8 \mathrm{~h}$ of cool down and standby. With this cycle schedule, three traps are provided for each reactor, with two spare primary traps for the total system. One secondary trap is also provided for each reactor.

\subsubsection{Alternatives}

An alternative to cold trapping for $\mathrm{UF}_{6}$ collection is condensation as a liquid. This technique is used in the diffusion plants for low enriched and depleted $\mathrm{UF}_{6}$ collection at withdrawal stations. Since the vapor pressure at the melting point $(64.2 \mathrm{C})$ of $\mathrm{UF}_{6}$ is about 1140 torr, it is necessary to have a $\mathrm{UF}_{6}$ stream with a low concentration of light gases. If the light gas fraction is too large, the gas must be compressed to pressures that are too high for safe operation in order to achieve the $\mathrm{UF}_{6}$ partial pressure required for condensation upon heat removal. In the diffusion plants the $\mathrm{UF}_{6}$ is purified by gaseous diffusion, with the "lights" $\left(\mathrm{N}_{2}\right.$ and $\left.\mathrm{O}_{2}\right)$ separated from $\mathrm{UF}_{6}$ at the top of the enrichment cascade in a section of diffusion equipment called the purge cascade. The $\mathrm{UF}_{6}$ is condensed at pressures and temperatures only a little over those at the melting point. The condenser outlet stream is returned to the cascade for further UF6/lights separation.

For the AVLIS UF 6 production system application, such a lights removal or purge system would require 4-10 stages, depending on stage type and the requirement for discharge $\mathrm{UF}_{6}$ concentrations. A low temperature (about $-80 \mathrm{C}$ ) cold trap is required for final $U F_{6}$ recovery from the vent stream. A schematic drawing of a system based on the so-called "rabbit" stage configuration is shown on flowsheet 4A in Appendix A.

The advantage of this method of product collection is that the system runs in a steady-state manner and product is collected continuously. Only one system is required. The thermal cycling of equipment is eliminated, along with any increased equipment replacement requirements that such constant cycling may cause, and the chance of operational incidents may be reduced due to simpler operating procedures. Costs have not been estimated for a purge/condensation design, but capital costs are not expected to differ greatly from those for cold trapping. Also, the availability of appropriate diffusion membrane material and compressor equipment may be a problem in deploying such a system.

Since the choice between cold trap collection and purge/condensation applies equally to the baseline and dry $\mathrm{UF}_{6}$ production systems, this option plays no role in a comparison between these two candidate flowsheets.

\subsection{UF6 Purification}

The liquid $\mathrm{UF}_{6}$ stream transferred from the $\mathrm{UF}_{6}$ collection system is expected to be contaminated with volatile fluorides. These are removed to the extent required to meet fuel fabricator acceptance criteria using fractional distillation supplemented, as required, by selective sublimation and sorbent trapping. 


\subsubsection{Advantages and Disadvantages}

The $\mathrm{UF}_{6}$ purification step is required in each of the dry $\mathrm{UF}_{6}$ production flowsheets considered. In the absence of wet chemical purification prior to conversion of enriched product to $\mathrm{UF}_{6}$, removal of volatile fluorides from the $\mathrm{UF}_{6}$ product is necessary to meet purity specifications.

Elements forming volatile fluorides include molybdenum, tungsten, vanadium, tantalum, and titanium. Some of these materials initially present in the enriched uranium metal may be eliminated in previous steps (e.g., retained in the diluent bed during fluorination). The compound forms to be expected have not definitely been established and may well be different when pod refurbishment oxides are being fluorinated.

\subsubsection{Technology Basis}

UF6 purification by fractional distillation is used by Allied Signal as a key part of their process for production of natural assay $\mathrm{UF}_{6}$. Many aspects of their distillation techniques are proprietary. For the specific contaminants of interest to the AVLIS application, additional data are needed to permit design of a system that will reliably provide the levels of impurity removal required to meet enriched uranium purity specifications.

\subsubsection{System Description}

A single distillation system is provided (two systems would be required for parallel processing of two streams at different isotopic assays). The system includes two columns with one removing the materials boiling at a higher temperature than $\mathrm{UF}_{6}$ and the other for the low boilers such as $\mathrm{WF}_{6}$ or $\mathrm{MoF}_{6}$. Available vapor pressure curves indicate that the high boiling components are much less volatile than UF6.

The system includes a reboiler in addition to the two rectification columns, each with associated reflux condenser, piping, instrumentation, and heating and cooling systems. Monel, nickel, and copper are suitable materials of construction. Each column is packed with monel wire mesh in three 6-ft sections. Depending on operating conditions this will provide approximately 20 stages. The reflux condensers and the reboiler are constructed with double-walled heat exchange tubing. Heating and cooling are accomplished using heat transfer fluids.

The $\mathrm{UF}_{6}$ is fed to the first column as a gas at one of two allowed feed points. The concentrated low boiler fraction is removed at the overhead reflux condenser. The reflux rate at this point is approximately four times the feed rate. The single reboiler supplies reflux vapor to both columns. Purified $U_{F}$ is removed at the top of the second column, which is half the height of the first column. The required reflux at this point is equivalent to only about one-half the vapor takeoff.

The less volatile reject stream is periodically drained from the reboiler into a transfer cylinder where it is allowed to solidify. After solidification the much more volatile $\mathrm{UF}_{6}$ is pumped off and returned to the distillation column. The more volatile reject material is removed as a vapor from the reflux condenser of the first column and desublimed in a small cold trap at $-80 \mathrm{C}$. This cold trap is warmed to an intermediate temperature and most of the volatile impurity along with some $\mathrm{UF}_{6}$ is purged through a sodium fluoride trap to a disposal system. Heating is continued to vaporize residual $\mathrm{UF}_{6}$ along with a small amount of impurity for return to the still. 


\subsubsection{Alternatives}

No alternative methods that are significantly different from those utilized in the described system have been identified and evaluated.

\subsection{Blending and Packaging}

The final $\mathrm{UF}_{6}$ product is blended to meet customer assay requirements and packaged into cylinders for later sampling and transfer into customer shipping cylinders.

\subsubsection{Advantages and Disadvantages}

Unless a program is established with fuel fabricators to ship UF6 product at the assays produced by the separators for blending at their facilities (a notion which may be prohibited by classification guidelines), isotopic blending of product to meet customer orders is necessary. Blending of pure $\mathrm{UF}_{6}$ to achieve a target assay can be done with high precision since tanks of $\mathrm{UF}_{6}$ to be used as blendstock can be fully homogenized and measured very precisely. Blending in another form, such as metal or $\mathrm{UF}_{4}$, would be less precise, and downstream processing on a campaign basis would provide substantial opportunity for isotopic adulteration.

The chief disadvantages of blending in pure $\mathrm{UF}_{6}$ form are the hazards associated with the accumulation and handling of liquid $\mathrm{UF}_{6}$ and the costs for equipment systems needed to assure a high level of safety.

\subsubsection{Technological Basis}

There are no technical issues associated with this portion of the system. The key issues are related to the safe processing and handling of liquid UF 6 . A final design for this system should incorporate the latest safety standards in use at gaseous diffusion plant facilities handling liquid $\mathrm{UF}_{6}$. The present preliminary design includes such provisions as does the corresponding system in the conceptual design of the baseline $\mathrm{UF}_{6}$ product system.

\subsubsection{System Description}

Purified $U_{6}$ product flows as a gas from the distillation system to a $U_{6}$ condenser and is collected and maintained as a liquid in double-containment accumulation vessels. Four vessels are included in the present design, each with a capacity of $3,000 \mathrm{kgU}$ as $\mathrm{UF}_{6}$ or about two days of system throughput. A larger capacity may be required to meet operational requirements, but accumulation vessel size should be kept as low as possible to minimize the inventory of liquid UF 6 with its associated safety hazards. At any time, one vessel is on line receiving product from the distillation system, one is in standby ready to go on line when needed, and the other two vessels are filled with product of two different assays for blending.

When an accumulation vessel is filled, its contents are isolated and allowed to fully homogenize by thermal mixing. An on-line corrosive gas mass spectrometer is then used to measure the isotopic assay of the vessel's contents based on a sample pulled from the gas phase above the accumulated liquid. With the assay of the contents of two vessels so determined, weighed amounts of material from the two accumulators are drained into a receiving cylinder to achieve the assay required by a customer order. To achieve blended assays lower than that of the lowest assay separator product, a hot-air autoclave is included in the design so that cylinders of natural assay $\mathrm{UF}_{6}$ can also be used for product blending. 
In most cases, the receiving cylinder is a 10-ton model (approximately $6,000 \mathrm{kgU}$ capacity) like the "parent" cylinders routinely filled at diffusion plant product withdrawal stations. If all 10-ton parent cylinders are assumed to be filled to capacity, the facility will fill and ship about eight cylinders each month. The actual number will be greater because some cylinders will not be completely filled. The filling/blending operation for each parent cylinder takes no more than $4 \mathrm{~h}$. Consistent with GDP practices, final liquid sampling of the blended contents of these cylinders and $\mathrm{UF}_{6}$ product transfer into fuel fabricator-owned 2.5-ton "daughter" cylinders is assumed to be accomplished at an existing GDP facility (either X-344 at Portsmouth or C-360 at Paducah).

\subsubsection{Alternatives}

The dry $\mathrm{UF}_{6}$ production system developed during the study was originally intended to have the capability of simultaneously processing two separator product streams of different assays, with final blending taking place as described. Since the baseline $\mathrm{UO}_{3} / \mathrm{UF}_{6}$ product system included in the conceptual design for the initial two-line $\mathrm{U}$ AVLIS plant did not have such parallel capability, changes were made to the dry process system to allow an equivalent comparison.

Campaign operation of product at different assays is considered to be feasible for either the baseline system or the dry process system. Parallel processing lines would increase operational flexibility and perhaps system availability. A detailed RAM (reliability, availability, maintainability) analysis would be required to determine if benefits are worth the added capital cost. This added cost is estimated to be roughly the same for both systems (in the range of $\$ 5$ million for either case).

For the baseline system, a second metal feed enclosure would be needed for the dissolution process and a second solvent extraction line is required. The rest of the system includes multiple units of equipment that could be readily separated into parallel process lines. For the dry process, a second distillation system would be required.

\subsection{Conversion of Refurbishment Oxides and Scrap Recovery}

\subsubsection{Refurbishment Oxide}

During separator pod refurbishment, enriched uranium oxide scrap is generated and collected. This material will contain iron at about $10 \mathrm{wt} \%$ on a metal basisand may contain somewhat higher levels of trace contaminants. However, it is expected to be a stream that, in general, is no less pure than the separator metal product. For scoping purposes, about $1 \%$ of the total separator product output can be considered to be in this form. Due to the economic value of the stream, it will be recovered as $\mathrm{UF}_{6}$ product.

Feasible options for processing this material include introducing it at the hydrofluorination step or at the fluorination step. In either case, the material could be fed and processed along with the standard product stream or accumulated and processed on a campaign basis. For purposes of this study, it has been assumed that the scrap oxide is fed at the fluorination step, either on a continuous basis or in campaign mode. The reason for bypassing the hydrofluorination step is a desire to maintain operation of the HF recovery/reboil system as nearly anhydrous as possible. Hydrofluorination of the scrap oxide would add water vapor to the gas stream exiting the hydrofluorination reactors. 


\subsubsection{Recovery of Other Scrap}

Due to the availability of a large solvent extraction system in the baseline product conversion facility, no separate wet chemical purification system is included in the plant conceptual design for recovery of uranium from miscellaneous plant scrap streams. The dry $\mathrm{UF}_{6}$ process has no such system capable of recovering the uranium from the ironuranium streams rejected from electron-beam distillation equipment (separator product recast and final product prepurification) as well as other plant scrap streams with significant concentrations of enriched uranium. These other streams that will likely be economically recoverable include scrap solutions and sample returns from analytical laboratories, solutions and vacuum cleaning accumulations related to container cleaning and maintenance, and decontamination solutions from selected equipment cleaning operations.

To compensate for the lack of a wet chemical purification system as an integral part of the product conversion facilities (as exists in the baseline $\mathrm{UF}_{6}$ production process), a capital and operating cost allowance is included in the cost estimates for the dry UF6 system to provide a small uranium recovery system based on conventional solvent extraction. The output of the system would be a reasonably pure stream of uranium oxide suitable for feeding to the fluorination reactors (along with refurbishment oxide scrap) and a dry raffinate ash similar to the waste stream from the baseline $\mathrm{UO}_{3}$ product system. The predominant component in the ash would be iron oxide.

No attempt has been made at this time to identify the specific plant facility that would house this recovery operation, since the choice is site dependent. The capital cost allowance is based on approximately $8,000 \mathrm{ft}^{2}$ of new building space meeting moderate hazard criteria, and both the capital and operating cost allowances are based on the assumption that the system is a part of a larger facility and shares various support functions and support staff. Because of the incremental capital and operating costs of the recovery system as well as the low enrichment level of the scrap streams (relative to the highly enriched uranium historically processed in GDP recovery facilities), the benefit to cost ratio of the recovery operation will not significantly exceed unity. In addition, the total volume of plant low level waste will not be significantly reduced; however, the total enriched uranium content of those wastes will be significantly lower. Benefits to plant operation that are difficult to quantify include reduced nuclear criticality safety concerns about waste streams, improved plant nuclear material accountability, and lower radioactivity levels per unit volume of waste. 


\section{Facility and Support System Design}

This section presents a summary description of facility and support systems included in the engineering design developed for the dry $\mathrm{UF}_{6}$ production system. This information supplements the more detailed descriptions of the uranium processing system provided in the previous section.

Design and cost data developed during conceptual design of the baseline $\mathrm{UF}_{6}$ product system were heavily used in generating the facility and support system information needed for this study. Building and system layout sketches were prepared to define the approximate size of the facility areas housing the uranium processes, HF storage, and $\mathrm{F}_{2}$ generation systems as well as support functions. Unit square foot costs derived from conceptual design information for the same types of facility spaces in the baseline plant design were then applied to these size requirements to determine facility costs.

\subsection{Electron-Beam Distillation Facility}

The electron-beam distillation system is housed within an expanded separator facility in the same general area housing the product recast system. As such, this prepurification system is considered to be part of the separator system (WBS 1.2). The additional building space estimated to be required for this system is an area $40 \mathrm{ft} x 50 \mathrm{ft}$, for a total of $2,000 \mathrm{ft}^{2}$.

\section{$3.2 \mathrm{HF} / \mathrm{F} 2$ Systems}

The HF storage and $F_{2}$ generation systems and associated buildings provided in the dry $\mathrm{UF}_{6}$ production system are basically the same as those included in the initial plant conceptual design for the baseline system. The principal difference is the number of $F_{2}$ generation cells. The baseline system, which directly fluorinates two-thirds of the plant's product, has eight operating cells. The dry $\mathrm{UF}_{6}$ process fluorinates all of the plant's product after it has first been converted to $\mathrm{UF}_{4}$. It is provided with 5 operating cells. The building space provided for $F_{2}$ generation is comparably smaller for the dry process system $\left(6,300 \mathrm{ft}^{2}\right.$ vs. $\left.9,300 \mathrm{ft}^{2}\right)$. The building space required for HF storage and $\mathrm{HF}$ receiving is the same for both systems $\left(5,700 \mathrm{ft}^{2}\right)$.

As in the conceptual design of the baseline system, the HF storage and HF receiving areas can be maintained at a temperature of about $4 \mathrm{C}$ to prevent any substantial $\mathrm{HF}$ vaporization in the unlikely event of a spill. These areas are designed as moderate hazard areas with reinforced concrete frame and continuous reinforced concrete walls and roof. The $\mathrm{F}_{2}$ generation area contains the electrolytic cells, the fluorine purification and handling system, and a cell refurbishment area. It is classified as a low hazard facility. It is a one-story structure, except for a mezzanine in the cell refurbishment area, with structural steel frame, insulated metal siding, and a built-up metal deck roofing system. The foundations for all structures are concrete.

\subsection{UF6 Production Building}

The $\mathrm{UF}_{6}$ production building contains about $49,300 \mathrm{ft}^{2}$ on two floors. The first floor has about $26,300 \mathrm{ft}^{2}$ and the second flour has about $23,000 \mathrm{ft}^{2}$. The height of each floor is $20 \mathrm{ft}$. The building is classified as a non-reactor nuclear facility and will comply with the requirements in DOE Order 6430.1A (reference 5) for a Uranium Processing and 
Handling Facility. As such, it also complies with the natural phenomena design criteria contained in UCRL-15910 (reference 6) for a moderate hazard usage category. The building has a slab on grade foundation and is constructed of reinforced concrete framing with continuous reinforced concrete walls and roof.

The building is arranged into three major operational areas: uranium processing, process support, and mechanical equipment areas. The uranium processing area consists of two parallel uranium conversion areas, each housing a uranium feed system, two hydrofluorination systems, two fluorination systems, and a $\mathrm{UF}_{6}$ collection system with seven primary and two secondary cold traps. These two parallel processing areas are supported by a common $\mathrm{UF}_{6}$ distillation area, a common receiving and storage area, and a common cylinder fill/blending area as well as common areas for feeding fresh diluent to the fluorination reactors and removing and packaging spent diluent.

Each of the unit operations in the conversion process is housed in a separate containment area which can be isolated from other operating systems. Each containment area is enclosed by fire walls and includes doors which exit to protected corridors.

The receiving and storage area provides for the receipt, accountability, and storage of incoming partially purified enriched metal from the separator facility. This area also provides space for storing and handling empty containers and for the receipt and storage of miscellaneous process consumables. The area is sized for storage of feed material to support facility operation for five days (about 40 canisters).

The cylinder fill/blending area houses the $\mathrm{UF}_{6}$ accumulators, the $\mathrm{UF}_{6}$ cylinder fill station, and the hot air autoclave. Filled cylinders are transferred outside for cool-down and solidification, with the cylinder movement system designed to avoid lifting cylinders while their contents are in liquid state. After full cool-down, the cylinders are transferred to the UF6 sampling and transfer facility.

The process support area houses off-gas treatment systems, waste handling systems, a laboratory, control room, local maintenance shop, personnel change facility, personnel monitoring station, and offices. The mechanical equipment areas house the HVAC equipment, utility systems, and electrical equipment.

\subsection{Other Auxiliary and Support Systems}

The cold trapping system is served by refrigeration equipment which supplies cold and hot brine for $\mathrm{UF}_{6}$ freeze-out and liquification. Equipment is provided like that included in the baseline $\mathrm{UF}_{6}$ system conceptual design.

The off-gas scrubber system is generally the same as that included in the small plant conceptual design except that the $\mathrm{KOH}$ scrubber solution is replaced with $\mathrm{Ca}(\mathrm{OH})_{2}$ and a $\mathrm{H}_{2} / \mathrm{F}_{2}$ burner is added.

Uninterruptible power supply and emergency diesel generator equipment is provided to support safety class systems. A house vacuum system and air monitoring network are needed to meet radiological protection requirements. Criticality monitors are included in the uranium processing areas.

The process control system is based on the same concept as used in the conceptual design of all U-AVLIS plant uranium processing systems. The computerized monitoring and control system provides top level system status information to the plant central control facility. 


\section{Capital and Operating Costs}

This section presents the capital and operating costs for the dry UF6 production system that were estimated during the study. The cost tables presented here include the corresponding baseline system costs for comparative purposes. Also, since the baseline system converts two-thirds of the small plant output to $\mathrm{UF}_{6}$ (one-third of product is shipped as $\mathrm{UO}_{3}$ ) while the dry $\mathrm{UF}_{6}$ process converts all product to this form, a third set of costs has been developed so that further comparisons can be made. These are labeled "modified baseline system." This system uses the wet route and converts all product to $\mathrm{UF}_{6}$, shipping none as $\mathrm{UO}_{3}$. This more costly approach is not the wet system recommended for deployment since it is expected that a third of the plant's output will be accepted by fuel fabricators as $\mathrm{UO}_{3}$. However, for those wishing to make a cost comparison between two systems that convert all product into the same form, costs for this modified baseline system are provided.

Costs are presented as current dollars and reflect labor costs and taxes applicable to the Paducah site case. Within the limits of the amount of cost estimate detail that could be developed during this study, efforts were made to use the same estimating methods and approach for the dry $\mathrm{UF}_{6}$ process as used to generate the cost estimate for the baseline process during plant conceptual design.

\subsection{Capital Costs}

Capital costs for the dry $\mathrm{UF}_{6}$ system, baseline system, and modified baseline system are given in Table 2. In the left-hand column, the corresponding plant project Work Breakdown Structure (WBS) element is identified. Each cost in the table includes a contingency allowance. Table 3 provides a summary of the contingency percentages that have been applied to each portion of the estimates. In many cases, these contingency percentages are the same as those used for the plant conceptual design because similar design assumptions were made and the same unit costs were used. For process steps that are unique to the dry process (hydrofluorination and $\mathrm{UF}_{6}$ distillation) and have no costing basis within the plant conceptual design, a considerably higher contingency percentage has been applied.

The cost estimates for the baseline and modified baseline systems are based on a greater amount of system evaluation and design detail than the cost estimate for the dry process. This leads to greater overall uncertainty in the dry process estimate. This estimate may exclude requirements that would be identified by more experimental work and additional design effort. It also may include equipment requirements derived from assumptions that would later be determined to be overly conservative.

The total capital cost for the dry UF6 system is estimated to be $\$ 144$ million. This cost is $\$ 45$ million, or $24 \%$, lower than the estimated capital cost of the baseline system ( $\$ 189$ million) and $\$ 53$ million, or $27 \%$, lower than that of the modified baseline system (\$197 million).

Ignoring any lack of technology demonstration data needed to execute a detailed system design, the time requirements for design, procurement, and construction of the dry $\mathrm{UF}_{6}$ system are judged to be essentially the same as those for the baseline system. Thus, apart from demonstration schedule constraints, which are potentially very important and are discussed in a later section, the deployment schedule for the dry process system is the same as that included for the baseline system in the initial plant conceptual design. 
Table 2

Capital cost comparison (current dollars $x$ 1000)

\begin{tabular}{|c|c|c|c|c|}
\hline WBS & Project Element & $\begin{array}{c}\text { Dry Path UF6 } \\
\text { System }\end{array}$ & $\begin{array}{c}\text { Baseline } \\
\text { System } \\
\left.\text { (UO }{ }_{3} / \mathbf{U F}_{6}\right) \\
\end{array}$ & $\begin{array}{l}\text { Modified } \\
\text { Baseline } \\
\text { (all UF } \text { UF }_{\text {) }} \\
\end{array}$ \\
\hline $\begin{array}{l}1.2 .1 \\
1.2 .4\end{array}$ & $\begin{array}{l}\text { Separator building } \\
\text { Uranium management (e-beam } \\
\text { distillation) } \\
\text { Total separator system }\end{array}$ & $\begin{array}{r}1,200 \\
6,300 \\
7,500\end{array}$ & $\begin{array}{l}0 \\
0 \\
0\end{array}$ & $\begin{array}{l}0 \\
0 \\
0\end{array}$ \\
\hline $\begin{array}{l}1.4 .1 \\
1.4 .2 \\
1.4 .3 \\
1.4 .4 \\
1.4 .5 \\
1.6 .3\end{array}$ & $\begin{array}{l}\text { UO3 } 3 \text { product building } \\
\text { UO3 } 3 \text { purification system } \\
\mathrm{UO}_{3} \text { conversion system } \\
\mathrm{UO}_{3} \text { support system } \\
\text { UO3 } 3 \text { product system integration } \\
\mathrm{UO}_{3} \text { product system controls } \\
\text { Total UO3 product system }\end{array}$ & $\begin{array}{l}0 \\
0 \\
0 \\
0 \\
0 \\
0 \\
0\end{array}$ & $\begin{array}{c}37,100 \\
12,500 \\
10,000 \\
32,500 \\
9,600 \\
4,500 \\
106,200\end{array}$ & $\begin{array}{c}37,100 \\
12,500 \\
8,200 \\
32,400 \\
9,400 \\
4,500 \\
104,100\end{array}$ \\
\hline $\begin{array}{l}1.5 .1 .1 \\
1.5 .1 .2 \\
1.5 .1 .3\end{array}$ & $\begin{array}{l}\text { UF6 production building } \\
\text { F}_{2} \text { generation building } \\
\text { HF storage building } \\
\text { Total UF } 6 \text { product buildings }\end{array}$ & $\begin{array}{c}24,600 \\
3,700 \\
4,000 \\
32,300\end{array}$ & $\begin{array}{c}17,100 \\
5,800 \\
4,000 \\
26,900\end{array}$ & $\begin{array}{c}18,300 \\
6,800 \\
4,000 \\
29,100\end{array}$ \\
\hline $\begin{array}{l}1.5 .2 .1 \\
1.5 .2 .2\end{array}$ & $\begin{array}{l}\text { HF storage system } \\
\text { F }_{2} \text { generation system } \\
\text { Total HF/F2 system }\end{array}$ & $\begin{array}{c}5,400 \\
9,300 \\
14,700\end{array}$ & $\begin{array}{c}5,600 \\
12,200 \\
17,800\end{array}$ & $\begin{array}{c}5,600 \\
14,900 \\
20,500\end{array}$ \\
\hline $\begin{array}{r}1.5 .3 .1 \\
1.5 .3 .2 \\
1.5 .3 .3\end{array}$ & $\begin{array}{l}\text { Hydrofluorination system } \\
\text { Fluorination system } \\
\text { UF6 collection system } 1 \\
\text { UF6 distillation } 2 \\
\text { Cylinder filling and sampling system } \\
\text { Total UF6 production system }\end{array}$ & $\begin{array}{c}14,800 \\
12,800 \\
15,100 \\
5,500 \\
3,600 \\
51,800\end{array}$ & $\begin{array}{c}0 \\
7,200 \\
10,800 \\
0 \\
3,600 \\
21,600\end{array}$ & $\begin{array}{c}0 \\
9,500 \\
12,900 \\
0 \\
3,600 \\
26,000\end{array}$ \\
\hline 1.5 .4 & Scrubber sol'n treatment & 2,400 & 2,900 & 2,900 \\
\hline 1.5 .5 & Process support systems ${ }^{3}$ & 7,200 & 4,200 & 4,400 \\
\hline 1.5 .6 & $\begin{array}{l}\text { UF } 6 \text { product system } \\
\text { integration }\end{array}$ & 11,200 & 7,500 & 8,500 \\
\hline 1.6 .3 & UF6 product controls ${ }^{4}$ & 4,800 & 1,400 & 1,400 \\
\hline 1.7 .3 & Uranium recovery system 5 & 12,000 & $\mathbf{0}$ & 0 \\
\hline & TOTAL COST & 143,900 & 188,500 & 196,900 \\
\hline
\end{tabular}

1 Includes off-gas treatment system for cold trap non-condensibles.

2 Includes off-gas treatment system for distillation system wastes.

3 Includes cost for analytical laboratory equipment for dry path system; no laboratory costs are included in baseline $\mathrm{UF}_{6}$ systems which share laboratory costed in $\mathrm{UO}_{3}$ system.

${ }^{4}$ For baseline systems, control system is costed on an incremental basis as an extension of $\mathrm{UO}_{3}$ control system using shared central hardware, control room, and software development.

$5_{\text {Allowance for wet recovery system for scrap processing. }}$ 
Table 3

Contingency percentages used for capital cost estimates

\begin{tabular}{|l|l|c|c|c|}
\hline WBS & \multicolumn{1}{|c|}{ Project Element } & $\begin{array}{c}\text { Dry Path UF6 } \\
\text { System }\end{array}$ & $\begin{array}{c}\text { Baseline } \\
\text { System } \\
\text { (UO 3/UF } 6)\end{array}$ & $\begin{array}{c}\text { Modified } \\
\text { Baseline } \\
\text { (all UF 6) }\end{array}$ \\
\hline 1.2 .1 & Separator building & 25 & - & - \\
\hline 1.2 .4 & Uranium management & 15 & - & - \\
\hline 1.4 .1 & UO3 product building & - & 25 & 25 \\
\hline 1.4 .2 & UO3 purification system & - & 22 & 22 \\
\hline 1.4 .3 & UO3 conversion system & - & 22 & 22 \\
\hline 1.4 .4 & UO3 support systems & - & -22 & 20 \\
\hline 1.4 .5 & UO3 product system integration & - & 20 & 20 \\
\hline 1.6 .2 & UO3 product controls & - & 20 & 25 \\
\hline 1.5 .1 & UF6 product buildings & 25 & 25 & 20 \\
\hline 1.5 .2 & HF/F2 systems & 20 & 20 & - \\
\hline 1.5 .3 .1 & Hydrofluorination & 35 & - & 25 \\
\hline & Fluorination & 25 & 25 & 25 \\
\hline 1.5 .3 .2 & UF6 collection & 25 & 25 & - \\
\hline & UF6 distillation & 35 & - & 25 \\
\hline 1.5 .3 .3 & Cylinder filling and sampling & 25 & 25 & 20 \\
\hline 1.5 .4 & Scrubber solution treatment system & 18 & 18 & 20 \\
\hline 1.5 .5 & Process support systems & 20 & 20 & 20 \\
\hline 1.5 .6 & UF6 product system integration & 20 & 20 & - \\
\hline 1.6 .3 & UF6 product controls & 20 & 20 & - \\
\hline 1.7 .3 & Uranium recovery system & 20 & & \\
\hline
\end{tabular}

\subsection{Annual Operating Costs}

Table 4 presents a summary comparison of the direct and indirect operating labor requirements for the three systems. Direct labor personnel are the actual system operating staff and their supervision. Indirect labor includes maintenance, laboratory, health physics surveyor, and production engineering support necessary for the day-to-day operation of the system. Additional plant support personnel (e.g., finance and human resources staff) that will add to the operating cost overhead borne by each of the systems are not included in the table. Uranium recovery system operating labor is not included for the dry process case.

Table 4

\section{Operating labor comparison (full-time equivalent employees)}

\begin{tabular}{|c|c|c|c|}
\hline System & Direct FTEs & Indirect FTEs & Total FTEs \\
\hline${\text { Dry } U_{6}^{6} \text { production system }}^{1}$ & $\overline{73}$ & $\overline{39}$ & 112 \\
\hline Baseline system & 76 & 40 & 116 \\
\hline Modified baseline system & 85 & 44 & 129 \\
\hline
\end{tabular}

${ }^{1}$ Excludes operating labor for uranium recovery system.

Annual costs of these labor requirements as well as all other operating costs for the three systems are summarized in Table 5. An allowance for annual operating costs for the uranium recovery system is included in the values for the dry UF 6 process. These data indicate that the dry process has an operating cost that is about $8 \%$ lower than that of the baseline system and $20 \%$ lower than the modified baseline system. 
Table 5

Annual Operating Cost Comparison (Current dollars $x$ 1000)

\begin{tabular}{|l|c|c|c|}
\hline \multicolumn{1}{|c|}{ Cost center } & $\begin{array}{c}\text { Dry UF6 } \\
\text { system }\end{array}$ & $\begin{array}{c}\text { Baseline } \\
\text { system }\end{array}$ & $\begin{array}{c}\text { Modified } \\
\text { baseline }\end{array}$ \\
\hline Direct labor & 3,200 & 3,400 & 3,800 \\
\hline Indirect labor & 1,600 & 1,700 & 1,900 \\
\hline Materials and equipment & 2,200 & 2,300 & 2,900 \\
\hline Utilities & 100 & 1,200 & 1,200 \\
\hline Power & 600 & 1,100 & 1,200 \\
\hline Waste management & 1,400 & 900 & 1,200 \\
\hline Allowance for uranium recovery system & 700 & 0 & 0 \\
\hline \multicolumn{1}{|c|}{ Total annual operating cost } & $\mathbf{9 , 8 0 0}$ & $\mathbf{1 0 , 6 0 0}$ & $\mathbf{1 2 , 2 0 0}$ \\
\hline
\end{tabular}

Waste management costs include the costs associated with providing long-term storage space for solid radioactive wastes, as assumed in the U-AVLIS plant conceptual design. If final disposal is required as the wastes are generated, waste management costs will increase.

Costs in the category of project operating expense (project OPEX) were not directly estimated for the dry $\mathrm{UF}_{6}$ system. These one-time project-related costs are generally proportional to annual operating costs. Since the annual operating costs for the dry process are similar to the baseline systems, it is expected that project OPEX costs will also be about the same for both processes. 


\section{Environmental, Safety, and Health Considerations}

Reference 1 provides a comprehensive listing of the environmental, safety, and health considerations associated with the dry $\mathrm{UF}_{6}$ production system and compares the ES\&H advantages and disadvantages of the dry and wet processes (refer to Table 8 on pages $42-43$ in that report). The overall conclusion of that evaluation was that neither the wet not the dry process presents any distinct advantage in this area. No new information has been developed during the recent study that leads to any different conclusion. However, additional quantitative data have been developed on the radioactive wastes generated by the dry UF 6 process. These are presented in Table 6 . Not included in Table 6 are the compactible low-level solid wastes (paper, plastic, gloves, etc.) that are generated by personnel engaged in operating and maintenance activities within the radiological areas of the process building.

Table 6

Estimated annual radioactive solid waste generation

\begin{tabular}{|c|c|c|c|c|c|c|c|}
\hline \multirow[b]{2}{*}{ Waste stream } & \multicolumn{5}{|c|}{ Waste component $(\mathrm{kg} / \mathrm{y})^{1}$} & \multirow{2}{*}{$\begin{array}{l}\text { Total } \\
\mathrm{kg} / \mathrm{y}\end{array}$} & \multirow{2}{*}{$\begin{array}{l}\text { Total } \\
\mathrm{ft}^{3} / \mathrm{y}\end{array}$} \\
\hline & $\mathrm{U}$ & $\mathrm{Fe}$ & $\mathrm{CaF}_{2}$ & $\mathrm{FeF}_{3}$ & Other & & \\
\hline E-beam reject ${ }^{2}$ & 40 & 60,000 & & & & 60,000 & 800 \\
\hline Bed diluent & 80 & & 65,000 & 13,000 & & 78,000 & 1,900 \\
\hline High-boil fraction & 40 & & & & 920 & 980 & 15 \\
\hline Low-boil fraction & 20 & & & & 970 & 1,000 & $\overline{15}$ \\
\hline NaF traps & 20 & & & & 140 & 170 & 6 \\
\hline Chemical traps & $<1$ & & & & 140 & 140 & 5 \\
\hline $\begin{array}{l}\mathrm{CaF}_{2} \text { from off-gas } \\
\text { treatment }\end{array}$ & $<1$ & & 22,000 & & & 22,000 & 650 \\
\hline $\begin{array}{l}\text { Waste from low boil } \\
\text { fraction processing }\end{array}$ & 2 & & 500 & & 820 & 1,300 & 40 \\
\hline Total & 200 & 60,000 & 88,000 & 13,000 & 3,000 & 164,000 & $\overline{3,400}$ \\
\hline
\end{tabular}

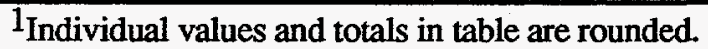

${ }^{2}$ Values reflect assumption that e-beam reject stream is processed in a uranium recovery system, with $99 \%$ recovery of uranium.

The total estimated radioactive waste generation rate is about $160,000 \mathrm{~kg} / \mathrm{y}$ or about 3,400 $\mathrm{ft} 3 / \mathrm{y}$. Two streams dominate. These are the electron-beam distillation system reject material and the spent reactor bed diluent. The e-beam reject material initially has a total mass of about $64,000 \mathrm{~kg} / \mathrm{y}$ and a uranium content of about 4,200 kgU/y (uranium content is about $7 \mathrm{wt} \%$ ). This material is assumed to be processed in the uranium recovery system, with a recovery factor of $99 \%$. The iron component remains in the recovery system raffinate stream, which is dried and calcined to produce iron oxide ash for disposal. The spent bed diluent has a larger mass than the material from the e-beam system but contains a substantially lower uranium concentration. This stream is not now considered to be a viable candidate for uranium recovery. A third stream, contaminated calcium fluoride sludge generated by neutralization of off-gas scrubber solution, has a relatively high mass and volume but is estimated to contain less than $30 \mathrm{ppm} \mathrm{U}$. 
The percent of uranium throughput to waste reflected in Table 6 is 0.03 . However, the table considers "theoretical" losses only. Actual overall facility losses experienced during operation will be higher (up to $0.1 \%$ ) due to process hold-up, measurement error, miscellaneous losses during powder handling, spills, etc. Within our ability to estimate, these values are about the same as the losses expected from the baseline process.

In this study the assumption has been made that the bed diluent must be changed out every 24 hours to prevent excessive accumulation of iron fluoride. This assumption determines the quantity of bed diluent waste and is probably conservative (allowing $\mathrm{FeF}_{3}$ accumulation in the bed to levels greater than $16 \%$ may be tolerable). Although additional uranium could be recovered by continued fluorination of the diluent before change-out or by leaching, the uranium losses are acceptably small and further treatment could only be justified if the resulting bulk material becomes disposable as conventional waste. Another option that could be investigated is the installation of equipment to remove most of the iron fluoride and restore the physical properties of the spent diluent to allow reuse in the fluorination reactors. 


\section{Development and Demonstration Requirements}

There is sufficient technical information to indicate that a dry $\mathrm{UF}_{6}$ production process based on the selected flowsheet is feasible. However, there is insufficient basic data for some aspects of the process to precisely define a system design. This basic data must be obtained if any further design is to be attempted. Beyond gathering this essential data, varying levels of engineering and pilot/prototype testing can be accomplished to increase the probability that the system will operate as intended (in terms of throughput capacity, purity of final product, amount of waste generation.and uranium losses, etc.) and/or to reduce the system's capital and operating costs by design optimization.

In determining the amount of engineering and pilot/prototype demonstration that is required, tradeoffs must be made among the following competing objectives:

- reducing the risk that the system will not perform to minimum requirements,

- reducing the amount of design conservatism that must be applied due to lack of information, and

- minimizing demonstration costs and timetables.

There should be a high level of confidence that the UF 6 production system deployed in support of the initial U-AVLIS plant will be capable of converting all separator product into $\mathrm{UF}_{6}$ meeting industry specifications. The following description of recommended development and demonstration activities is based on achieving this for the dry UF6 process. Comparisons with the baseline process are also given in Section 6.2.

\subsection{Recommended Development and Demonstration Activities}

\subsubsection{Electron-Beam Distillation}

The electron-beam distillation system for final product prepurification, if retained in the flowsheet, should be demonstrated in concert with similar activities for the separator product recast system. For both applications, iron reduction to the target value ( $3 \mathrm{wt} \%$ for product recast and $1 \mathrm{wt} \%$ for final product prepurification) is required while minimizing uranium losses. The same engineering scale hardware can be used to verify system performance for both applications as long as the system permits variation of uranium flow rate in the crucible and electron-beam power. Feedstock at varying iron concentrations can be fed to a system with a crucible that is substantially shorter than that planned for the production system to verify performance within different segments of the planned full-size system.

Beyond confirmation that the system will achieve the required level of iron removal without excessive uranium losses, assuring a high level of mechanical reliability will likely require full-scale prototype testing. Casting the product at the end of the crucible can be performed with confidence based on separator pod splat-caster demonstrations. However, a possible concern is reliable segregated collection and removal of distillate from the upstream and downstream sections of the crucible. The final design throughput rate and the resulting required system availability factor will better define the degree to which operational reliability must be assured.

Plans for demonstrating electron-beam distillation for separator product recast are not fully established at this time. When these plans have been developed, the incremental cost cani be quantificd for activities required to demonstrate the product prepurification system that go beyond the work done in the separator program. 


\subsubsection{Hydrofluorination}

Laboratory studies - It is necessary to repeat and expand the limited metal hydrofluorination experiments performed 50 years ago, emphasizing rates, product characteristics, and effects of impurities (particularly iron concentration). Since the kinetics of low temperature hydrofluorination seem to depend on the intermediate hydriding reaction, some initial hydriding experiments are warranted. By varying reactor temperature, hydrogen partial pressure, and flow, information on kinetics and equilibria can be obtained for various iron concentrations and metal piece sizes.

Some metal hydriding experiments are planned within the separator program to support pod refurbishment system design. This effort will provide data over the next six months that may reduce the additional lab scale work required for metal hydrofluorination.

Hydrofluorination test conditions should initially be set on the basis of the hydriding experiments, and the effects of temperature, iron composition, and flow should be determined. Based on the results of the Ames work, the small-scale apparatus must be provided with a means of vibrating the reacting feedstock to achieve satisfactory rate data. Information on iron conversion and volatilization of impurities should be gathered.

Engineering scale tests - Design, construction, and operation of a sub-scale test reactor is strongly recommended. The reactor type should be chosen to mimic that being proposed for the production system so that satisfactory scale-up data may be obtained. The reactor should be capable of processing up to a few $\mathrm{kgU} / \mathrm{h}$. The necessary support systems for supply and disposal of $\mathrm{HF}$ and $\mathrm{H}_{2}$ will be a major part of the facility cost, and the design feed rate should be kept to the minimum required to provide a satisfactory test bed. Based on the investment required in the peripheral systems, it may be feasible to design and construct a second reactor based on an alternate concept.

The reactor testing period is expected to occur over a three month period for each reactor type. The first month is occupied in calibrations and safety checks. Startup exercises occupy two weeks with the actual runs being performed over the period of a month. The remaining two weeks is occupied with shut-down and clean-out work. If a second reactor type is tested, two months would be required to remove the first unit and install the second unit. The tests can be expected to consume several hundred kilograms of uranium for each reactor type. The $\mathrm{UF}_{4}$ produced could be saved for possible fluorination testing.

Prototype scale tests - The need for prototype scale testing depends on the results of engineering scale work and the level of full-scale design verification and optimization that is desired. Parts of the system such as those for feeding and heat transfer may require separate testing. Based on the information now available, prototype testing of hydrofluorination equipment should be assumed.

\subsubsection{Metal Oxidation Alternative}

As an alternative or backup approach to metal hydrofluorination/UF 4 fluorination, it is recommended that laboratory work on uranium metal oxidation methods be performed while the initial hydrofluorination lab work is being done. If problems are encountered with metal hydrofluorination, the uranium oxide could be converted to $\mathrm{UF}_{6}$ either by direct fluorination or by hydrofluorination to $\mathrm{UF}_{4}$ followed by fluorination. The laboratory experiments should investigate air or steam oxidation or a variation of the steam method which uses an initial hydriding reaction to increase the rate of conversion to oxide. Results of the hydriding tests performed as a precursor to the hydrofluorination work will be of direct use. In addition to the separator program's metal hydriding experiments discussed in section 6.1.2, some work has been done on AVLIS metal alloy oxidation in steam and dry air. Results of this work could be used as a guide to determine what additional experimental data should be gathered here. 
Based on the laboratory data gathered for both hydrofluorination and oxidation, a decision can be made whether or not to add this step to the process flowsheet. Any flowsheet revisions made at this point will alter the follow-on demonstration activities. Based on information currently available, both engineering and prototype scale tests may be necessary.

\subsubsection{UF 4 Fluorination}

Unless the $\mathrm{UF}_{4}$ produced by metal hydrofluorination has very unusual characteristics, the issues for this step are much the same as for the oxide fluorination step of the baseline wet process. Heat transfer aspects of the design will be simplified due to $\mathrm{UF}_{4}$ 's reduced heat of reaction to $\mathrm{UF}_{6}$.

Any consideration of bypassing the prepurification step in the dry $\mathrm{UF}_{6}$ process will lead to a more complex fluorination system (such as the two-step fluorination reactor concept discussed in section 2.3.4), which would have added demonstration requirements. Pilot prototype scale testing could be required to achieve optimal elutriation of iron fluoride from the bed diluent and to assure adequate clean-up of the continuous diluent removal stream. Such testing might be avoided by a more conservative design which provides additional reactor capacity to compensate for increased down-time for off-line bed changeout, if required.

Some laboratory tests of fluorination of scrap refurbishment oxide may be useful to assure that there will be no unexpected problems when feeding this scrap stream to the fluorination reactors. These could perhaps be done as an adjunct to other work. However, since this stream will constitute only about $1 \%$ of the total product flow and it will be in a form that should readily fluorinate, a substantial effort for this material is not justified. At a minimum, chemical analyses should be performed on prototype refurbishment oxides to identify any impurities or impurity levels that might pose special problems for final purification by distillation.

\subsubsection{UF 6 Purification}

Distillation system design requires basic phase equilibrium data for impurities forming volatile fluorides. This includes information on solubility in $\mathrm{UF}_{6}$, volatility relative to $\mathrm{UF}_{6}$, pure component volatility, etc. Some of these data are already available for the possible impurities. Additionally, several pilot plant distillation studies are reported. Nevertheless, the identity, quantity, and possible chemical compound makeup for AVLIS product impurities are felt to be sufficiently different from past situations that basic phase diagram studies are needed to determine relative volatilities and solubilities in binary and multi-component mixtures.

Depending on the results of these lab tests, it may be advisable to perform small scale distillation tests in the lab to validate calculated separations and qualitatively determine possible operating problems. Also, some lab scale tests of selective sorption for final removal of problem impurities may become necessary. Such tests would involve 1 to 2inch sorption columns about $4 \mathrm{ft}$ high or use of thin bed reactors with gas recirculation to obtain kinetic and loading data independent of overall column effects.

It would be possible to design a workable distillation system from laboratory data like that described above if a conservative design approach is used. If judged necessary based on the laboratory experiments, an engineering scale unit could be employed to optimize the design. 


\subsubsection{Component Testing for Baseline and Dry UF 6 Processes}

Common to both the baseline system for $\mathrm{UF}_{6}$ production from pure $\mathrm{UO}_{3}$ and the dry $\mathrm{UF}_{6}$ production system, there are certain anticipated requirements for component testing to reduce deployment risks. These testing requirements include work related to cold traps, solids handling equipment, and auxiliaries such as valves and process filters.

\subsection{Development and Demonstration Costs and Schedule}

The total incremental cost for development and demonstration work recommended in section 6.1 for the dry process is estimated to be $\$ 23$ million. Incremental costs exclude program management, costs for building space, and other fixed costs. These estimated costs are preliminary and are based on the work being performed at locations that remain to be determined. The site for the work is assumed to have an existing infrastructure for safe handling and management of $\mathrm{HF}, \mathrm{UF}_{6}$, and $\mathrm{F}_{2}$. Costs will be higher if this assumption is not satisfied. Nothing is included in these costs at present for electron-beam distillation demonstration activities. These costs also do not include any work beyond laboratory scale experiments for $\mathrm{UF}_{6}$ distillation (although larger scale testing may be needed) and do not include any prototype testing of a more complex fluorination reactor design that may be required if the prepurification step is omitted from the flowsheet.

In comparison to this initial estimated demonstration cost for the dry $\mathrm{UF}_{6}$ process, the estimated incremental cost for demonstration activities associated with the baseline system is about \$20 million, which is composed of about \$13 million for the non-fluoride portion of this system (production of pure $\mathrm{UO}_{3}$ ) and $\$ 7$ million for the $\mathrm{UF}_{6}$ portion. The $\$ 13$ million expenditure is required to continue the work necessary to achieve the recommended goal of a non-fluoride AVLIS product form which avoids the hazards, wastes, and added costs of product conversion to $\mathrm{UF}_{6}$. The limited expenditures for $\mathrm{UF}_{6}$ production for the baseline process, which are for component testing, reflect the fact that the wet process is based on commercially available technologies. The demonstration requirements and associated costs for the baseline process have gone through several years of evaluation and refinement and are known to a higher degree of certainty than the corresponding information for the dry process.

The schedule for completing the recommended demonstration work for the dry process is estimated to require 4-5 years. Figure 4 presents a simple diagram of this schedule. A corresponding schedule of 3-4 years will be required to complete the ongoing and planned demonstration activities for the baseline process. Several important plant project schedule dates related to product conversion facilities are as follows. These are applicable to the licensed, two-line plant project which begins in mid-FY1993.

Start product conversion Title I design

Start product conversion Title II design (building)

Initiate product conversion long-lead procurements and construction

Complete product conversion Title II design

Begin AVLIS plant production
September, 1993

March, 1995

August, 1996

December, 1996

January 2001 


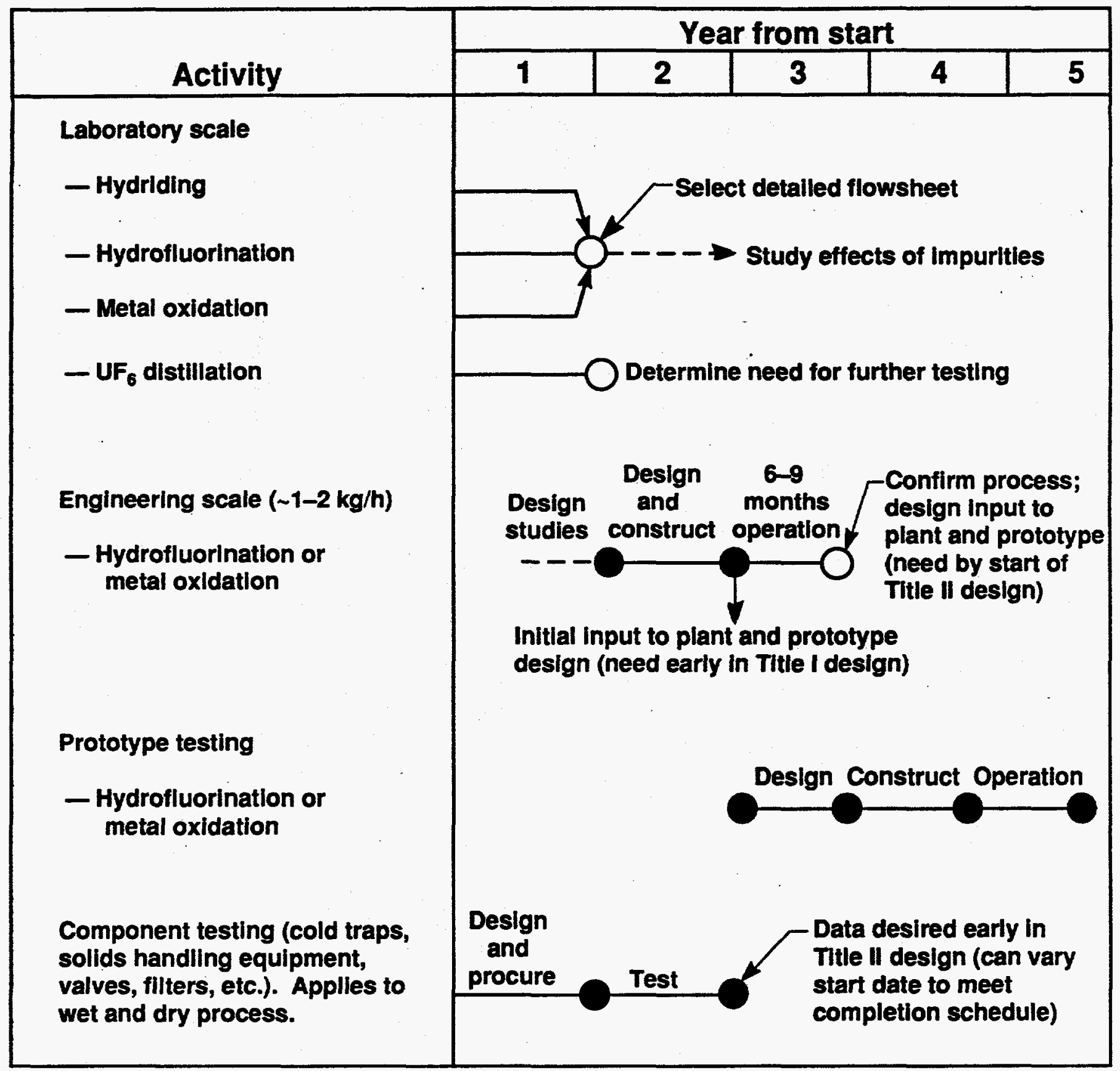

Figure 4. Dry $\mathrm{UF}_{6}$ production process development and demonstration schedule.

Based on the demonstration schedule and plant project schedule, laboratory and engineering scale data for the dry UF6 process would be obtained in parallel with Title I engineering design and would be available to provide input to Title II design. Prototype testing work would be conducted in parallel with Title II design; therefore, if the results of this testing do not confirm the design in progress, then some redesign, and hence increased design costs would occur. If the redesign is extensive, delays in plant construction could result. For the baseline system, all recommended prototype testing data will be available early in Title II design to provide a high level of confidence that the system will perform as intended. 


\section{Conclusions and Future Actions}

Conclusions of the technical and engineering evaluation have confirmed and better quantified conclusions reached by the UF6 Product Alternatives Review Committee. General conclusions and summary information are presented below and in Table 7.

- The dry $\mathrm{UF}_{6}$ production system has a lower capital cost than the baseline system due to fewer overall process steps, leading to less equipment and smaller process facilities. The dry system is estimated to cost $\$ 144$ million, compared to the baseline system cost of $\$ 189$ million and the modified baseline system cost of $\$ 197$ million.

- Annual operating costs for the dry system are slightly less than those for the baseline systems.

- A small uranium recovery system based on conventional solvent extraction is desirable in the U-AVLIS plant if the dry UF6 process is employed for product conversion. Capital and operating cost allowances for such a system are included in the costs for the dry process. The economics of scrap recovery are marginal, but the quantity of enriched uranium in plant waste streams is substantially reduced.

- There are a variety of possible alternate flowsheets for a dry UF6 system; avoidance of the e-beam distillation step is especially desirable to avoid the associated scrap generation. Additional study is required to determine if this can be accomplished without adding substantially to process uncertainties and/or to the costs and schedules for hydrofluorination and fluorination equipment demonstration.

- Although the hydrofluorination step appears sound for pure uranium metal as demonstrated in the Manhattan Project, the magnitude of the effects of contaminants, especially iron, on rates and conversion has not been explored.

- Estimated demonstration costs for the dry $\mathrm{UF}_{6}$ process total about $\$ 23$ million, assuming it is subsidized by separator product recast system work. None of these costs support non-fluoride processing. Corresponding demonstration costs for the baseline system are $\$ 20$ million, of which about $\$ 13$ million supports non-fluoride processing.

- Dry process demonstration activities require 4-5 years; laboratory and engineering scale data would be available for Title II design, but prototype testing of hydrofluorination (and possibly e-beam) equipment would be performed in parallel; therefore, if the results of the testing do not confirm the design in progress, then some redesign, and hence increased design costs would occur. If the redesign is extensive, delays in plant construction could result. Demonstration activities for the baseline process can be completed in time to provide the required data for Title II design.

Based on these conclusions, it is recommended that current activities in support of the baseline product conversion process continue as planned. In parallel, plans should proceed to contract with qualified industrial firms to evaluate the conceptual design of the baseline process and the dry process design prepared in this study. These evaluations will provide an industrial perspective and establish a further basis for deciding what experimental work is warranted for the dry process. In addition, the following actions are suggested:

- Perform additional trade-off studies to determine if dry process flowsheet modifications, such as elimination of electron-beam distillation and/or replacement of hydrofluorination with steam or air oxidation, offer advantages such as reduced production costs or reduced demonstration needs.

- Establish options for carrying out prototype scale experiments involving fluoridebearing chemicals and $\mathrm{UF}_{6}$ and define associated facility costs for these demonstrations. 
Table 7

Comparison of Baseline and Dry UF 6 Processes

\begin{tabular}{|c|c|c|}
\hline Parameter & $\begin{array}{c}\text { Baseline } \mathrm{UO}_{3} / \mathrm{UF}_{6} \\
\text { Process }\end{array}$ & Dry $\mathrm{UF}_{6}$ Process \\
\hline Capital cost (x 1000) & $\$ 189,000$ & $\$ 144,000$ \\
\hline $\begin{array}{l}\text { Annual operating cost }(x 1000) \\
\text { including U losses }\end{array}$ & $\$ 11,000$ & $\$ 10,000$ \\
\hline \multicolumn{3}{|c|}{ Recommended development and demonstration activities } \\
\hline Dissolution & $\begin{array}{l}\text { Lab scale in progress } \\
\text { Engr. scale in progress } \\
\text { Prototype scale planned }\end{array}$ & Not applicable \\
\hline Solvent extraction & $\begin{array}{l}\text { Lab scale in progress } \\
\text { Prototype scale in progress }\end{array}$ & Not applicable \\
\hline Denitration & $\begin{array}{l}\text { Engr. scale planned } \\
\text { Prototype scale planned }\end{array}$ & Not applicable \\
\hline E-beam distillation & Not applicable & $\begin{array}{l}\text { Engr. scale recommended } \\
\text { Prototype scale recommended }\end{array}$ \\
\hline Hydrofluorination & Not applicable & $\begin{array}{l}\text { Lab scale recommended } \\
\text { Engr. scale recommended } \\
\text { Prototype scale recommended }\end{array}$ \\
\hline Fluorination & Component tests planned & Component tests recommended \\
\hline Product collection & Component tests planned & Component tests recommended \\
\hline $\mathrm{UF}_{6}$ purification & Not applicable & $\begin{array}{l}\text { Lab scale recommended } \\
\text { Larger scale TBD }\end{array}$ \\
\hline $\begin{array}{l}\text { Demonstration costs } \\
\text { (incremental) }\end{array}$ & $\begin{array}{l}\$ 20 \text { million, of which } \$ 13 \\
\text { million also applies to non- } \\
\text { fluoride based processing }\end{array}$ & $\begin{array}{l}\text { \$23 million, none of which } \\
\text { applies to non-fluoride based } \\
\text { processing; e-beam requires up } \\
\text { to additional } \$ 10 \text { million if not } \\
\text { funded by product recast efforts }\end{array}$ \\
\hline Technical risk & $\begin{array}{l}\text { Overall low technical risk, } \\
\text { based on processes used in the } \\
\text { past within DOE and industry }\end{array}$ & $\begin{array}{l}\text { Overall moderate risk: risk will } \\
\text { be reassessed after laboratory } \\
\text { tests; risk mitigated by } \\
\text { availability of process step } \\
\text { alternatives but changing } \\
\text { flowsheet in mid-course will } \\
\text { increase cost and schedule }\end{array}$ \\
\hline Deployment risk & $\begin{array}{l}\text { Low; design data easily } \\
\text { obtained on schedule for plant } \\
\text { deployment }\end{array}$ & $\begin{array}{l}\text { Moderate to significant; meets } \\
\text { deployment schedule with } \\
\text { difficulty; much of Title I } \\
\text { design done before lab and } \\
\text { engr. scale tests complete and } \\
\text { Title II design done in parallel } \\
\text { with prototype tests }\end{array}$ \\
\hline $\begin{array}{l}\text { Compatibility with non-fluoride } \\
\text { based processing }\end{array}$ & $\begin{array}{l}\text { If properly designed, plant can } \\
\text { supply either } \mathrm{UF}_{6} \text { or } \mathrm{UO}_{3} ; \\
\text { much of demonstration effort } \\
\text { supports both fluoride and non- } \\
\text { fluoride based processing }\end{array}$ & $\begin{array}{l}\text { Plant can only be used to } \\
\text { supply UF6; demonstration } \\
\text { supports only fluoride based } \\
\text { processing }\end{array}$ \\
\hline
\end{tabular}

* If this plant converted all of its $\mathrm{UO}_{3}$ to $\mathrm{UF}_{6}$, it would have a capital cost of $\$ 197$ million and annual operating cost of $\$ 12$ million/yr. 


\section{References}

1991.

${ }^{1}$ UF $_{6}$ Product Alternatives Review Committee - Final Report, L-13411, September

$2 U$-AVLIS Production Plant Conceptual Design Report (Draft), LP-91-142,

volume 6 (UO 3 Product System) and volume 9 (UF6 Product System), July, 1991.

${ }^{3} U-A V L I S$ Two-Separator Module Production Plant Primary Criteria, L-12669, April 1991.

${ }^{4}$ Annual Book of ASTM Standards, volume 12.01.

${ }^{5}$ General Design Criteria, DOE Order 6430.1A, April 1989.

6 Design and Evaluation Guidelines for Department of Energy Facilities Subjected to Natural Phenomena Hazards, UCRL-15910, June 1990. 


\section{Appendix}

The flowsheets on the following pages were prepared as part of the engineering design work for the dry UF6 process. An alternate flowsheet for a possible purge/condensation system for $\mathrm{UF}_{6}$ collection is included, as is a preliminary engineering drawing of a hydrofluorination reactor.

The system capital cost estimate was prepared after preparation of these drawings, and some changes were made to maintain consistency between the dry and wet processes, where appropriate. The flowsheets were not revised to reflect these changes, which are listed below:

- The number of $F_{2}$ generation cells was reduced from 6 to 5 .

- The number of primary cold traps was reduced from 16 to 14 .

- The number of $\mathrm{UF}_{6}$ distillation systems was reduced from 2 to 1.

- The number of on-line mass spectrometers in the product blending system was increased from 1 to 2 . 


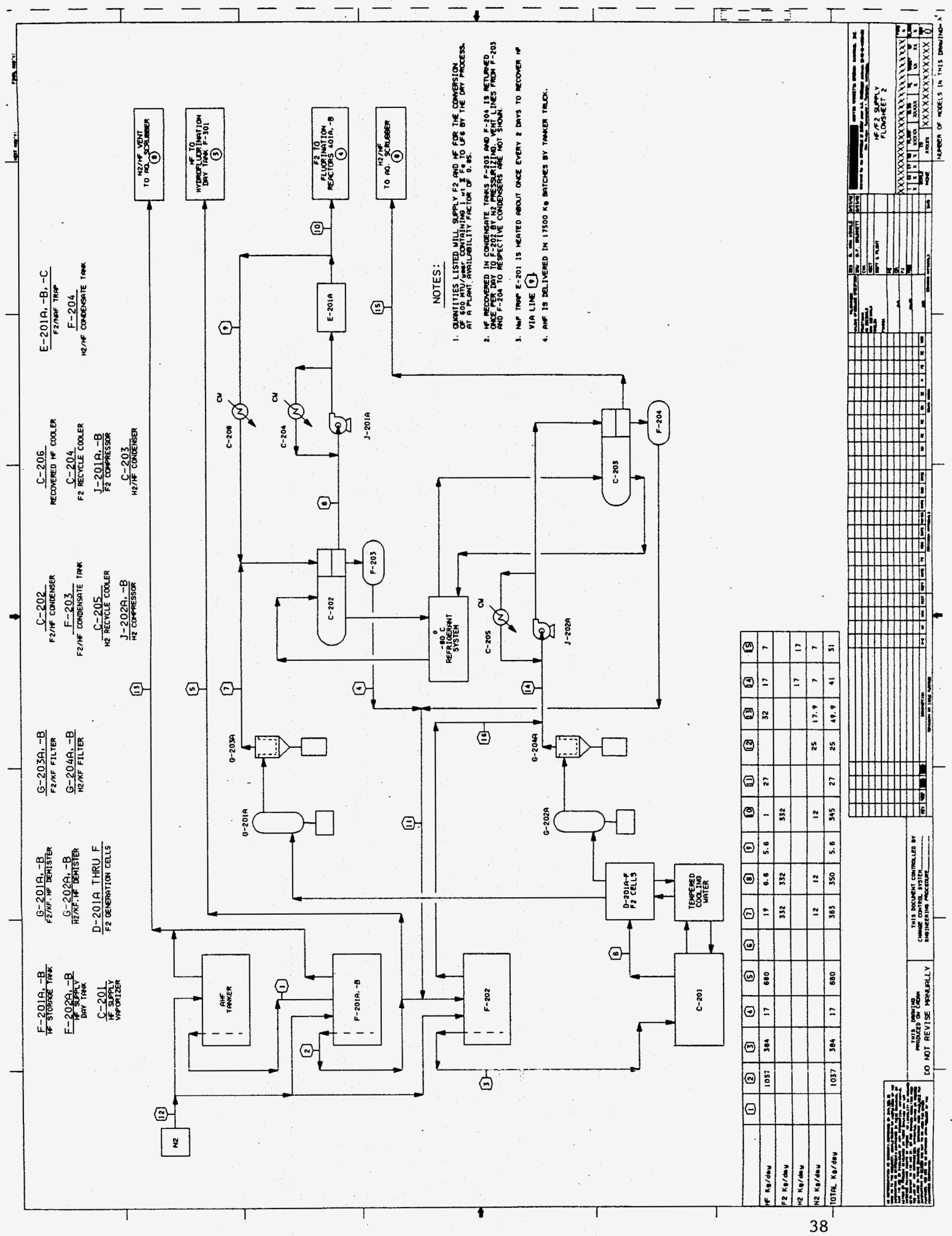









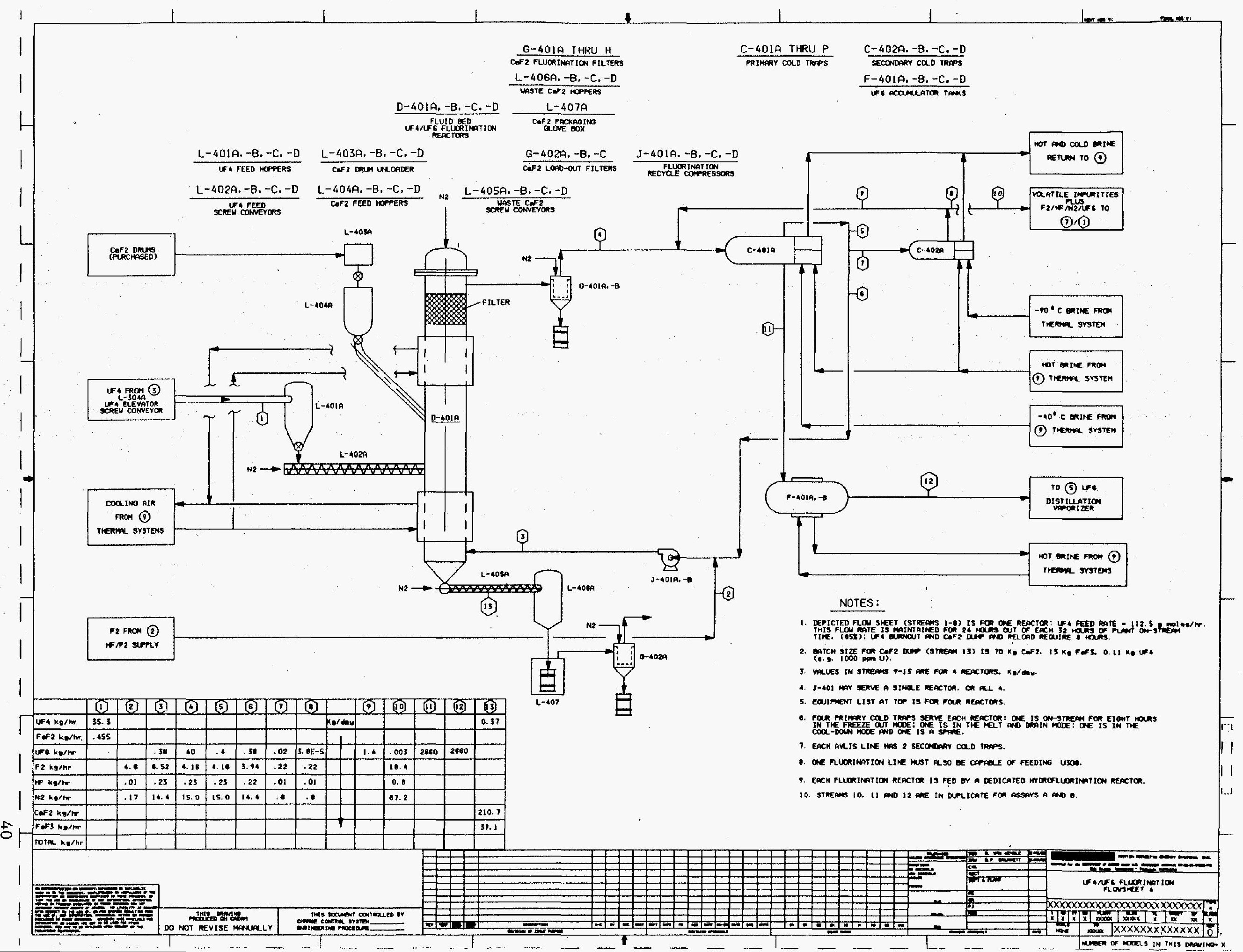




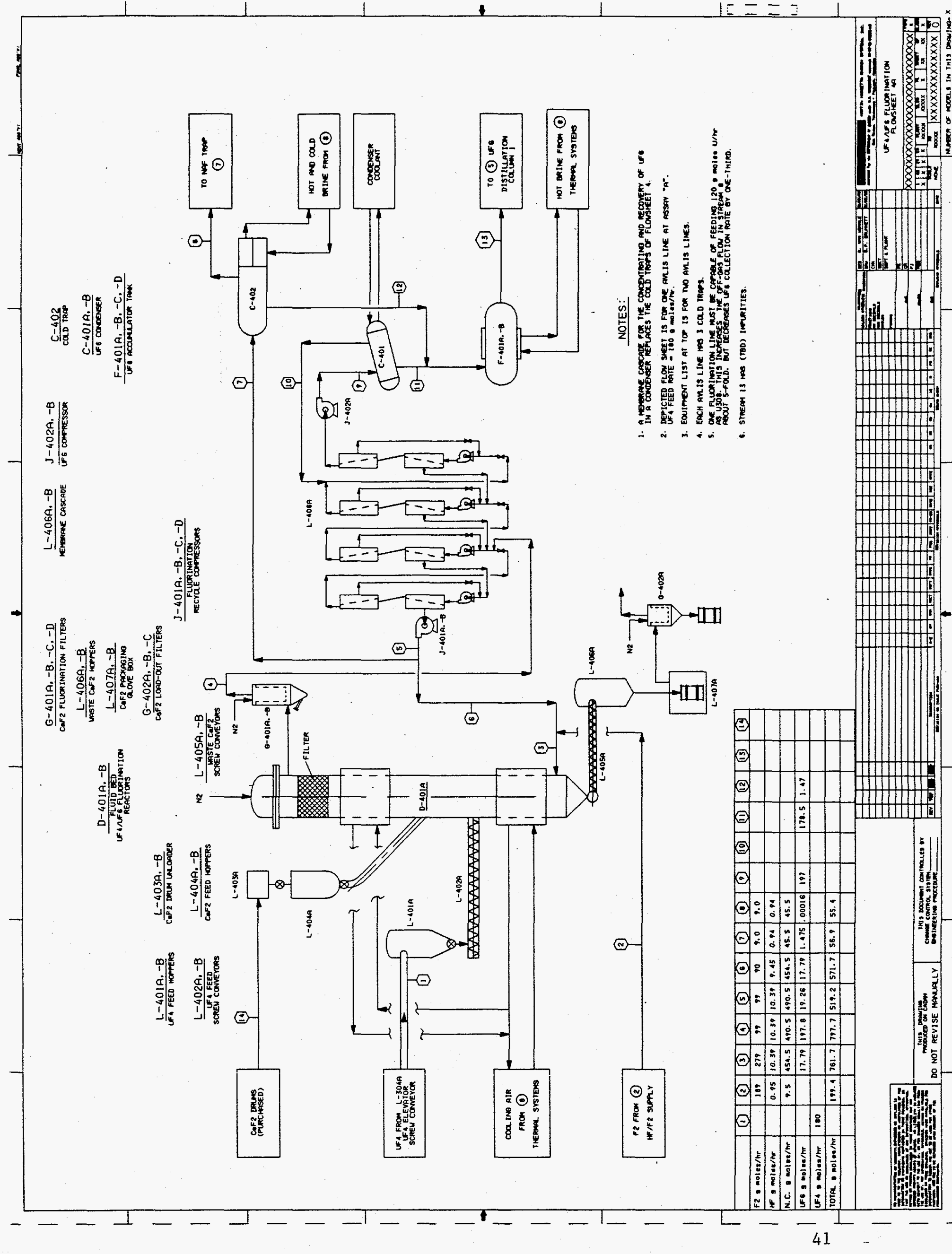




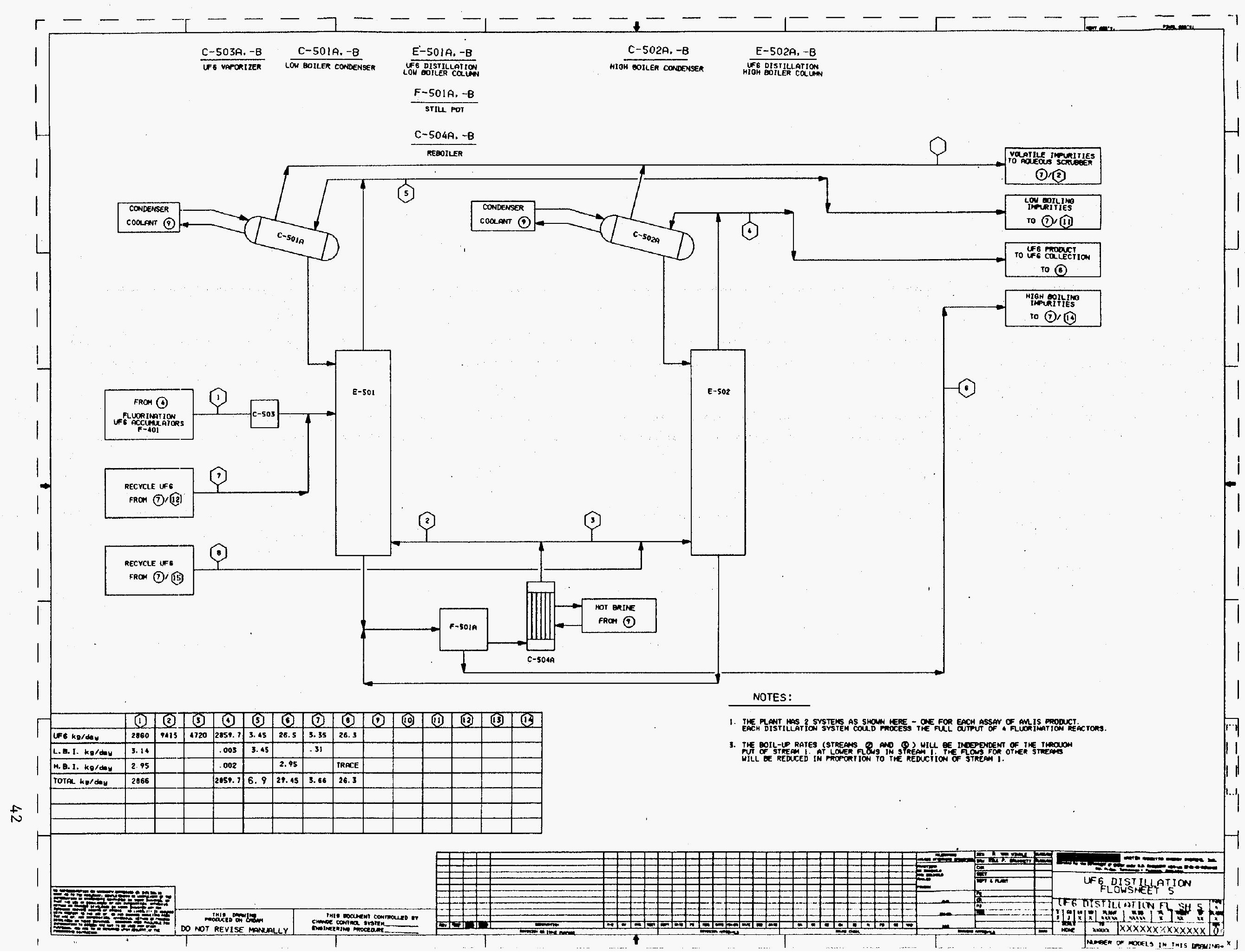




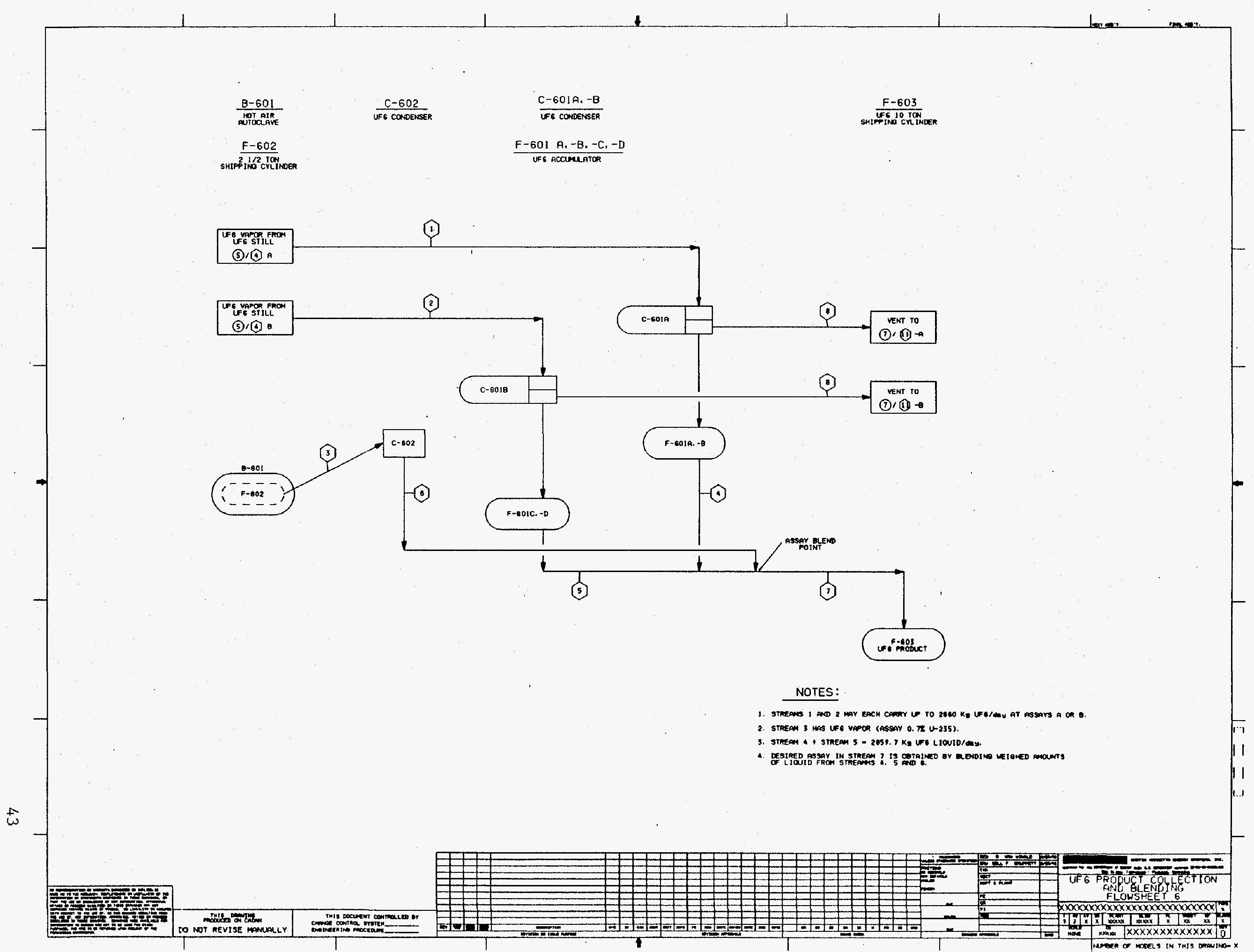




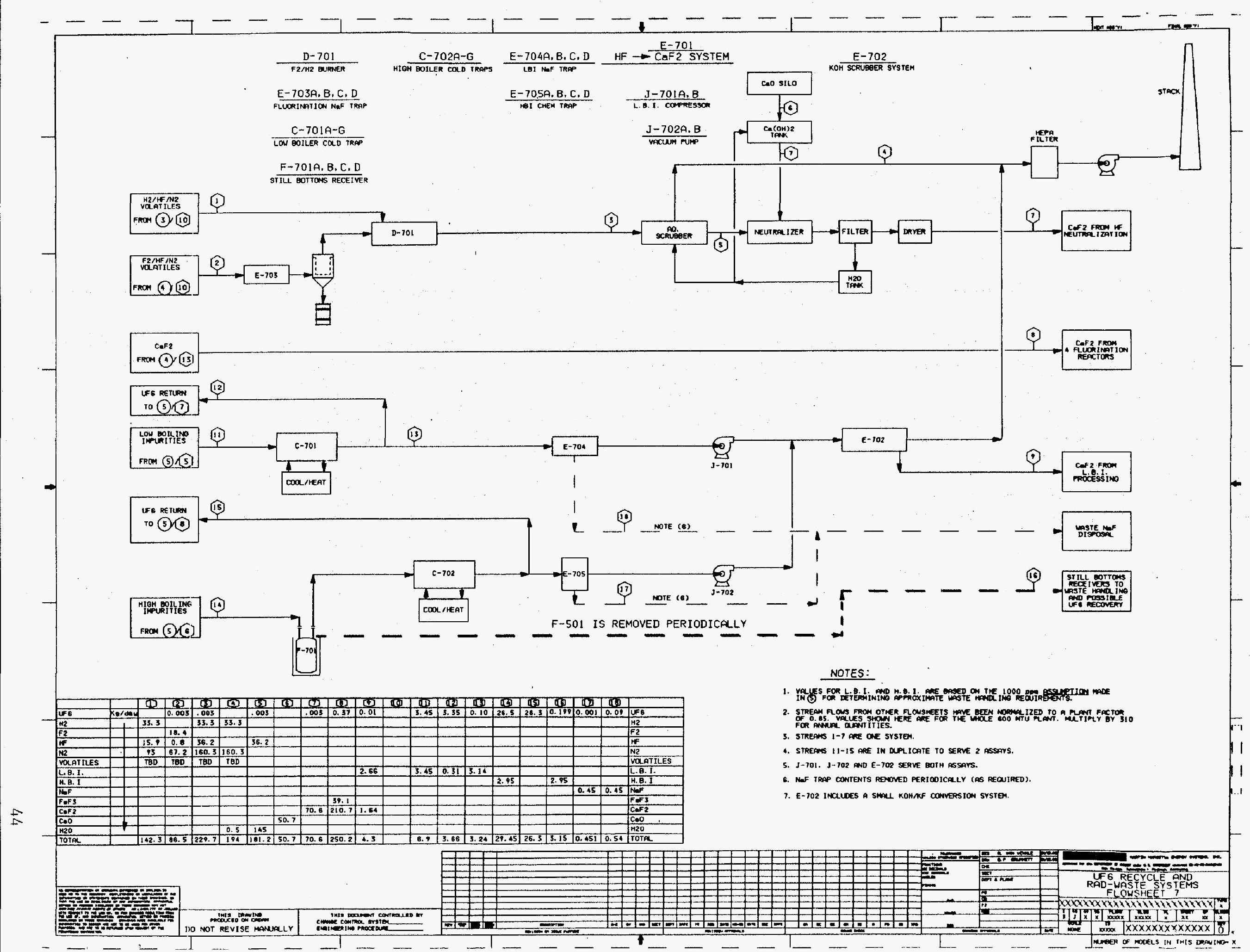




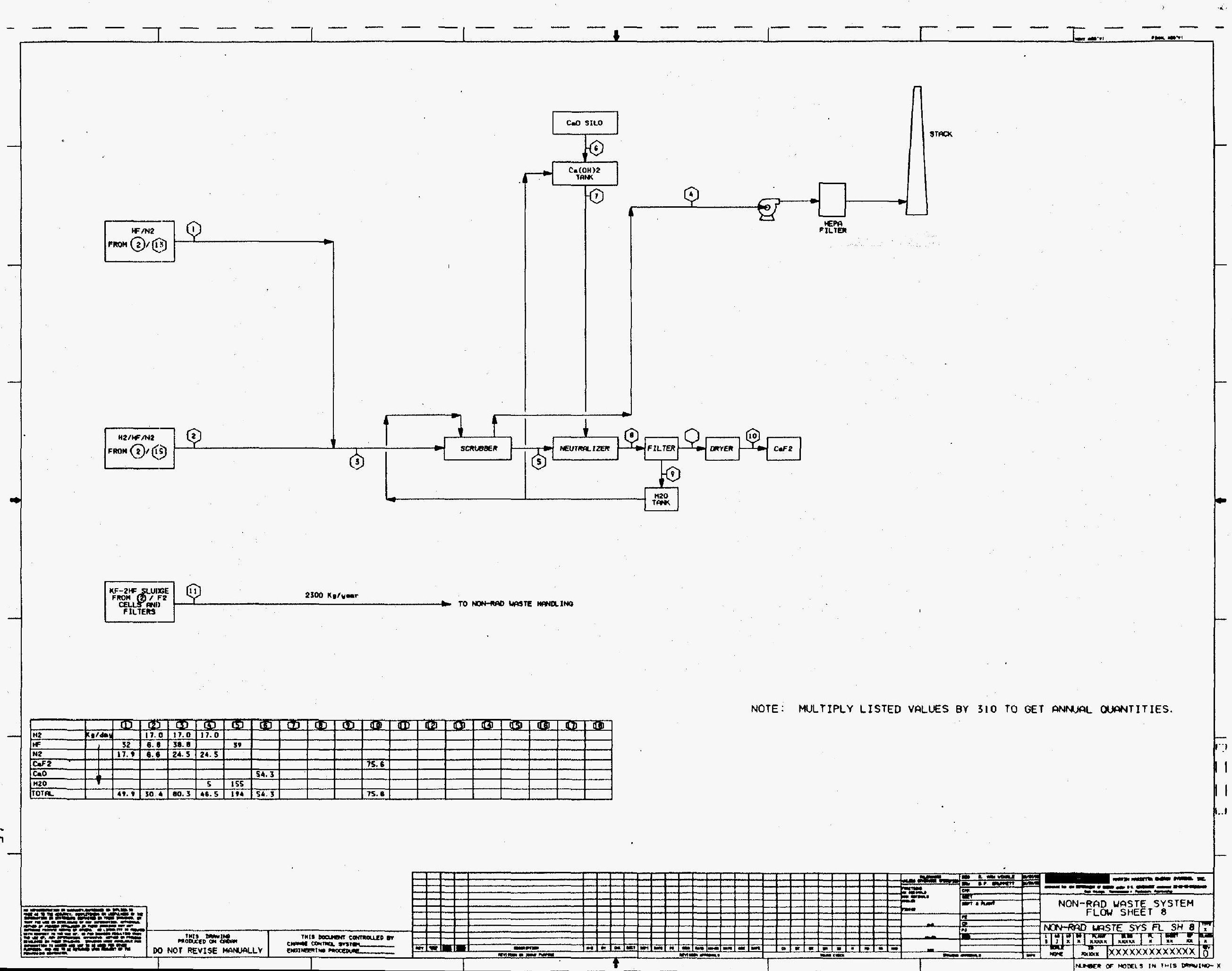




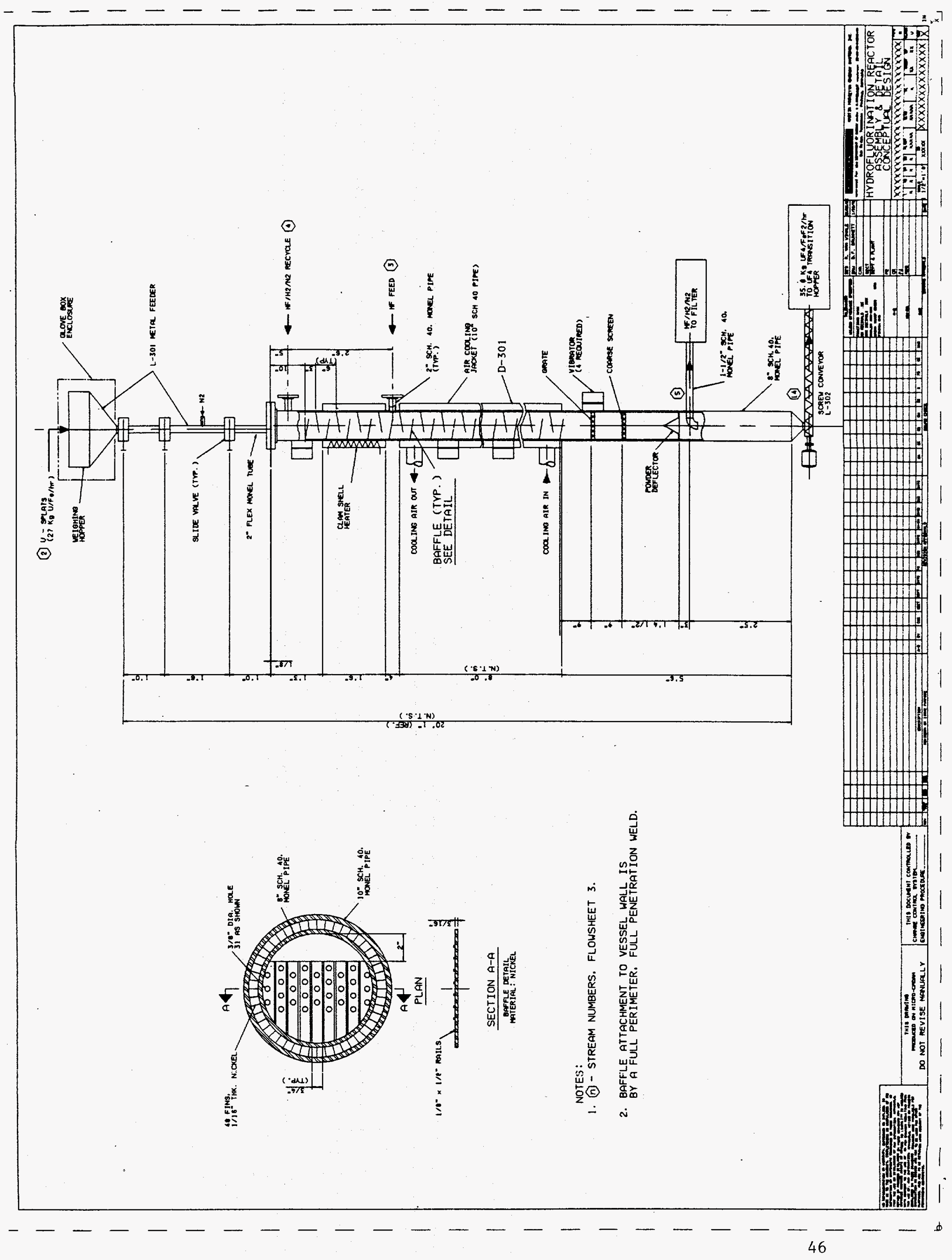




\section{Distribution}

\section{Internal Distribution}

Laser Programs

$\begin{array}{ll}\text { Andrews, D.H. } & \text { L-467 } \\ \text { Chen, H-L } & \text { L-466 } \\ \text { Dubrin, J.W. } & \text { L-466 } \\ \text { Early, J.T. } & \text { L-466 } \\ \text { Feinberg, R.M. } & \text { L-466 } \\ \text { Hargrove, R.S. } & \text { L-466 } \\ \text { Harri, J.G. } & \text { L-466 } \\ \text { Hoglund, R.L. } & \text { L-467 } \\ \text { Horton, J.A. } & \text { L-464 } \\ \text { Humphreys, S.R. } & \text { L-467 } \\ \text { Miller, R.R. } & \text { L-467 } \\ \text { Rittenhouse, P. } & \text { L-496 } \\ \text { Stern, R.C. } & \text { L-467 } \\ \text { Yatabe, J.M. } & \text { L-466 } \\ \text { CLYA Files (4) } & \text { L-468 }\end{array}$

\section{External Distribution}

Martin Marietta Energy Systems

Anderson, W.C.

Bryan, C.B.

Fields, W.E.

Jamison, J.R.

Lundberg, L.A.

Merriman, J.R.

Pashley, J.H.

Schneider, P.G.

Snider, J.W.

\section{Department of Energy}

U.S. DOE-OUE, Germantown, MD

Haberman, N. (5)

NE-35

U.S. DOE-ORO, Oak Ridge, TN

Hall, J.C.

Hughlett, J.

Parks, J.

U.S. DOE-SAN, Oakland, CA

Chang, T.D. (3) 
External Distribution

Siemens Power Corp., Richland, WA 